University of Wollongong

Research Online

Faculty of Engineering and Information

Faculty of Engineering and Information

Sciences - Papers: Part A

Sciences

$1-1-2014$

\title{
The effect of processing parameters on the microstructure and mechanical properties of low-Si transformation-induced plasticity steels
}

\author{
Fayez Alharbi \\ University of Wollongong, fa854@uowmail.edu.au \\ Azdiar A. Gazder \\ University of Wollongong, azdiar@uow.edu.au \\ Andrii Kostryzhev \\ University of Wollongong, andrii@uow.edu.au \\ Bruno C. De Cooman \\ Pohang University of Science and Technology \\ Elena Pereloma \\ University of Wollongong, elenap@uow.edu.au
}

Follow this and additional works at: https://ro.uow.edu.au/eispapers

Part of the Engineering Commons, and the Science and Technology Studies Commons

\footnotetext{
Research Online is the open access institutional repository for the University of Wollongong. For further information
} contact the UOW Library: research-pubs@uow.edu.au 


\title{
The effect of processing parameters on the microstructure and mechanical properties of low-Si transformation-induced plasticity steels
}

\author{
Abstract \\ A base low $\mathrm{Si}$, high-A1 transformation-induced plasticity (TRIP) steel and one with $0.03 \mathrm{Nb}$ and $0.002 \mathrm{Ti}$ (wt \\ percent) additions were subjected to thermo-mechanical processing (TMP) and galvanising simulations. \\ $\mathrm{T}$ \\ Keywords \\ effect, low, transformation, induced, plasticity, si, microstructure, steels, mechanical, parameters, \\ processing, properties \\ Disciplines \\ Engineering | Science and Technology Studies

\section{Publication Details} \\ Alharbi, F., Gazder, A. A., Kostryzhev, A., De Cooman, B. C. \& Pereloma, E. (2014). The effect of processing \\ parameters on the microstructure and mechanical properties of low-Si transformation-induced plasticity \\ steels. Journal of Materials Science, 49 (7), 2960-2974.
}




\section{Journal of Materials Science}

\section{The Effect of Processing Parameters on the Microstructure and Mechanical Properties of Low Si Transformation Induced Plasticity Steels

\author{
--Manuscript Draft--
}

\begin{tabular}{|c|c|}
\hline Manuscript Number: & JMSC34819R2 \\
\hline Full Title: & $\begin{array}{l}\text { The Effect of Processing Parameters on the Microstructure and Mechanical Properties } \\
\text { of Low Si Transformation Induced Plasticity Steels }\end{array}$ \\
\hline Keywords: & $\begin{array}{l}\text { TRIP steel, thermo-mechanical processing, galvanising, intercritical annealing, tension, } \\
\text { microstructure, mechanical properties, scanning electron microscopy (SEM), } \\
\text { transmission electron microscopy (TEM). }\end{array}$ \\
\hline Corresponding Author: & $\begin{array}{l}\text { Fayez Alharbi, Masters } \\
\text { University of Wollongong } \\
\text { Fairy Meadow, New South Wales AUSTRALIA }\end{array}$ \\
\hline \multicolumn{2}{|l|}{$\begin{array}{l}\text { Corresponding Author Secondary } \\
\text { Information: }\end{array}$} \\
\hline First Author: & Fayez Alharbi, Masters \\
\hline \multicolumn{2}{|l|}{ First Author Secondary Information: } \\
\hline \multirow[t]{5}{*}{ Order of Authors: } & Fayez Alharbi, Masters \\
\hline & Azdiar A Gazder, PhD \\
\hline & Andrii Kostryzhev, PhD \\
\hline & Bruno C De Cooman, PhD \\
\hline & Elena V Pereloma, PhD \\
\hline
\end{tabular}




\title{
The Effect of Processing Parameters on the Microstructure and Mechanical Properties of Low Si
}

Transformation Induced Plasticity Steels

\section{Fayez Alharbi1 ${ }^{1,2}$, Azdiar A. Gazder ${ }^{1,2}$, Andrii Kostryzhev ${ }^{1}$, Bruno C. De Cooman ${ }^{3}$, Elena V. Pereloma ${ }^{1,2}$}

${ }^{1}$ School of Mechanical, Materials and Mechatronic Engineering, University of Wollongong, New South Wales 2522, Australia

2Electron Microscopy Centre, University of Wollongong, New South Wales 2519, Australia ${ }^{3}$ Materials Design Laboratory, Graduate Institute of Ferrous Technology, Pohang University of Science and Technology, Pohang, South Korea

\begin{abstract}
A base low $\mathrm{Si}$, high $\mathrm{Al}$ TRansformation Induced Plasticity (TRIP) steel and one with $0.03 \mathrm{Nb}$ and $0.02 \mathrm{Ti}$ (wt.\%) additions were subjected to thermo-mechanical processing (TMP) and galvanising simulations. The microstructure and mechanical properties were analysed using a combination of optical and electron microscopy, X-ray diffraction and tensile testing and the results compared with those from intercritically annealed - galvanised steels. The addition of $\mathrm{Nb}$ and $\mathrm{Ti}$ results in microstructure refinement and an increase in the amount of the retained austenite after TMP which in turn, leads to increases in the tensile strength $(\sim 750 \mathrm{MPa})$ and the total elongation $(\sim 29 \%)$. A deterioration in the volume fraction of retained austenite and the mechanical properties was noted in both steels after the additional galvanising simulation. For the base steel, all TMP and galvanised samples presented with continuous yielding during tensile testing. The $\mathrm{Nb}$-Ti steel exhibited discontinuous yielding and extended Lüders banding when TMP was followed by a longer coiling time. Both steels returned discontinuous yielding after the intercritical annealing - galvanising treatment. The discontinuous yielding behaviour was associated with the much finer ferrite grain size in the intercritically annealed steels and the ageing processes that take place during galvanising.
\end{abstract}

Keywords: TRIP steel, thermo-mechanical processing, galvanising, intercritical annealing, tension, microstructure, mechanical properties, scanning electron microscopy (SEM), transmission electron microscopy (TEM).

\footnotetext{
*Corresponding Author: Fayez Alharbi

e-mail: fa854@uowmail.edu.au

Tel: + 61242215507 | Fax: + 61242213662
} 


\section{Introduction}

Since the transformation induced plasticity (TRIP) effect was first characterised by Zackay et al. [1], an enormous amount of research has been undertaken to understand the mechanism in detail and to introduce further improvements in TRIP-assisted steels. The latter class of steels is distinguished by their high strengths and elongation; both of which are key material parameters of interest to the automotive industry [2-5]. A typical TRIP steel microstructure consists of polygonal ferrite (PF) as the major phase along with varying fractions of bainite (B) and retained austenite (RA) and a minor phase of martensite (M). It has been suggested that the most important prerequisite for obtaining a desired combination of mechanical strength and ductility in TRIP steels [6,5] is the formation of a significantly high volume fraction of RA with sufficient stability. The volume fraction and stability of the RA is controlled by varying the chemical composition of the steel and/or processing parameters such as the magnitude of deformation and the coiling temperature/time. For example, while coiling at $465{ }^{\circ} \mathrm{C}$ compared to $400{ }^{\circ} \mathrm{C}$ led to an increase in the volume fraction of the RA [7], an intermediate coiling time resulted in an even larger volume fraction of RA [8]. On the other hand, Takahashi and Bhadeshia [9] found that even with a 15\% volume fraction of RA, the improvement in uniform elongation was only $2 \%$ such that the further gains in ductility were the direct result of the contribution and interaction between the other phases and/or microstructural constituents [10,11].

Silicon is an important element that enhances the TRIP effect. Its high solubility in ferrite and low solubility in cementite suppresses the formation of the latter phase $[3,12]$. Thus, Si leads to a further carbon enrichment of the RA and a subsequent lowering of the martensite formation temperature. Furthermore, Si addition increases the mechanical strength by solid solution strengthening and it is claimed that co-alloying with $\mathrm{P}$ multiplies this effect. Barbe et al. [12] investigated the influence of $\mathrm{P}$ on a base $0.19 \mathrm{C}-1.68 \mathrm{Mn}-0.48 \mathrm{Si}-0.84 \mathrm{Al}$ steel with additions of $0.015 \mathrm{P}$ and $0.066 \mathrm{P}$ (wt.\%). The study observed that the P increases the volume fraction and stability of the RA during prolonged bainitic transformation.

Microalloying additions of carbide or carbo-nitride forming elements such as $\mathrm{Nb}$ or Ti are used for microstructure refinement and to gain even further increases in mechanical strength [13-15]. Nb not only refines and strengthens ferrite but also mechanically stabilises the RA by reducing its size [16] and increasing its volume fraction [17].

Since a high Si content in TRIP steel usually degrades the adhesion of Zn during automotive sheet galvanising by the formation of a thin surface oxide layer, the element is usually substituted with Al. While some studies have found that $\mathrm{Al}$ substitution further stabilises the RA at room temperature and results in mechanical property improvements compared to Si-only TRIP steels [18], other investigations have suggested that the TRIP effect of $\mathrm{Al}$ is less than that of $\mathrm{Si}$ [19]. However, since the galvanisability of high Al TRIP steels is far better than high Si TRIP steels [7,20], significant resources have been devoted towards the further development of high Al TRIP steels using cold rolling and intercritically annealed (IA) techniques. 
The production of TRIP steels by controlled thermo-mechanical processing (TMP) has distinct advantages over cold rolled and intercritically annealed methodologies as it reduces the number of processing stages and accordingly, decreases the cost of production while simultaneously boosting productivity. Initial attempts to produce thermo-mechanically processed TRIP steels have resulted in very good mechanical property combinations [20-22]. In the case of high Si steels, it has been shown that $25 \%$ thickness reduction in the austenite recrystallisation region followed by $47 \%$ thickness reduction in the non-recrystallisation region above $A_{r 3}$ results in the highest amount of the RA with optimum stability leading to an enhancement of mechanical strength and ductility [22].

In order to characterise TRIP steel behaviour during forming operations, different emprirical models have been proposed to describe the rate of work hardening during uniform straining. While the Hollomon model [23] is limited to interpreting the work hardening behaviour of single phase steels, other impirical equations such as the Ludwik [24], Voce [25], Swift [26] and Ludwigson [27] relationships have only been partially satisfactory in interpreting complex phase steels [2]. Studies on dual phase steels $[28,29]$ have shown that the modified Crussard-Jaoul (C-J) model (which is based on the Swift relationship) sucessfully describes its two stage work hardening behaviour. In multiphase TRIP steels, the work hardening rate is controlled by the dislocation accumulation mechanism as well as by the strain-induced austenite transformation [10]. Thus, further model modifications have to account for the evolving volume fraction and the strength of the various phases at different strains [30,31]. Since the work hardening rate of TRIP steels is typically characterised by three stages [31], the dynamic composite model [30] has been found to be the more appropriate.

This paper focuses on the effect of thermo-mechanical processing and subsequent galvanising simulations on the microstructure-property relationships in a base low Si TRIP steel and another with $\mathrm{Nb}$ and $\mathrm{Ti}$ additions. Further comparisons between these steels have also been made with their intercritically annealed counterparts. Since information on the evolving volume fraction of each phase at different strains is not available during tensile tesing, the present study applies the modified C-J equations to charcterise the work hardening behaviour.

\section{Experimental and analytical procedure}

A base low Si TRIP steel and another with further $\mathrm{Ti}$ and $\mathrm{Nb}$ additions (Table 1 ) were received as $6 \mathrm{~mm}$ thick hot rolled plate from GIFT-POSTECH. The three processing schedules conducted on 8 $(\mathrm{RD}) \times 20(\mathrm{TD}) \times 6(\mathrm{ND}) \mathrm{mm}^{3}$ samples (Figs. 1a, 1b and 2) using a Gleeble 3500 thermo-mechanical simulator are summarised as follows: (i) thermo-mechanical processing with a short (TMP-S) and, (ii) a long coiling time (TMP-L) and, (iii) TMP-L followed by a typical industrial galvanising treatment (TMP-LG).

In the case of the first and second schedules (Fig. 2a), the samples were heated at $2 \mathrm{Ks}^{-1}$ to $1250{ }^{\circ} \mathrm{C}$, held for $120 \mathrm{~s}$ followed by cooling to $1100{ }^{\circ} \mathrm{C}$ where a $25 \%$ roughing reduction was applied. The samples were then held for $120 \mathrm{~s}$ in order to condition the recrystallised austenite and then 
cooled down to the finish rolling temperature in the non-recrystallised austenite region $\left(\mathrm{T}_{\mathrm{FR}}=850{ }^{\circ} \mathrm{C}\right.$ for the base steel and $875{ }^{\circ} \mathrm{C}$ for the $\mathrm{Nb}$-Ti steel). Following a second $47 \%$ finishing reduction, the samples were slow cooled at $1 \mathrm{Ks}^{-1}$ to the accelerated cooling start temperature $\left(\mathrm{T}_{\mathrm{AC}}=680{ }^{\circ} \mathrm{C}\right.$ for the base steel and $690{ }^{\circ} \mathrm{C}$ for the $\mathrm{Nb}$-Ti steel) to form $\sim 50 \%$ polygonal ferrite. At the $\mathrm{T}_{\mathrm{AC}}$ temperature, the cooling rate was further increased to $20 \mathrm{Ks}^{-1}$ to avoid pearlite formation. Finally, the sample was held at $470{ }^{\circ} \mathrm{C}$ coiling temperature $\left(\mathrm{T}_{\mathrm{C}}\right)$ for different coiling times $\left(\mathrm{t}_{\mathrm{c}}\right)$ to form bainite and then water quenched. When $t_{c}=125 \mathrm{~s}$, the short coiling time samples are denoted as TMP-S whereas when $t_{c}=$ $1200 \mathrm{~s}$, the long coiling time samples are referred to as TMP-L.

In the case of the third industrial galvanising schedule (Fig. 2b), the TMP-L samples were reheated at $25 \mathrm{Ks}^{-1}$ to $550{ }^{\circ} \mathrm{C}$ and held for $25 \mathrm{~s}$ to allow for carbon segregation at the surface of hot rolled steel and avoid the formation of a silicon oxide layer [32,33]. The samples were then cooled at 5 $\mathrm{Ks}^{-1}$ to $\mathrm{T}_{\mathrm{C}}=465{ }^{\circ} \mathrm{C}$ (above the zinc melting point), held for $5 \mathrm{~s}$ and air cooled to room temperature.

In order to compare the efficacy of the TMP-S treatment, an intercritically annealedgalvanising (IA-G) schedule was also undertaken on the two steels at GIFT-POSTECH. As shown in Fig. 2 c, cold rolled samples of both steels were reheated to a temperature within the intercritical (ferriteaustenite) region $\left(\mathrm{T}_{\mathrm{IA}}=863{ }^{\circ} \mathrm{C}\right.$ for the base steel and $871^{\circ} \mathrm{C}$ for the $\mathrm{Nb}$-Ti steel) and held for $120 \mathrm{~s}$ to form $\sim 50 \%$ polygonal ferrite followed by rapid cooling at $30 \mathrm{Ks}^{-1}$ to the isothermal bainite formation temperature $\left(\mathrm{T}_{\mathrm{C}}=465{ }^{\circ} \mathrm{C}\right)$. The sample was held at this temperature for a total of $125 \mathrm{~s}$ in order to account for bainite formation during the first $120 \mathrm{~s}$ and thereafter, galvanising in a zinc pot for $5 \mathrm{~s}$. This was followed by air cooling at $30 \mathrm{Ks}^{-1}$ to room temperature.

From the above, it is understood that the isothermal bainite formation stages for the TMP-S and IA-G schedules are similar as holding was undertaken for $125 \mathrm{~s}$ at $\mathrm{T}_{\mathrm{C}}=470{ }^{\circ} \mathrm{C}$ and $465{ }^{\circ} \mathrm{C}$, respectively.

The microstructure was characterised by a combination of optical microscopy and secondary and transmission electron imaging. The austenite and martensite phases were distinguished optically using Klemm's [34,35] colour etchant. Here the weak nature of the etched film [35] resulted in colour scheme inconsistencies in some samples. Secondary electron imaging of the $\mathrm{Nb}$ - $\mathrm{Ti}$-rich precipitates was undertaken on a JEOL JSM-7001F field emission gun - scanning electron microscope at 3-15 kV accelerating voltage. The determination of the chemical composition of 20-25 precipitates after the TMP-L (base and Nb-Ti steels) and the TMP-LG (Nb-Ti steel) schedules was performed using an Oxford Instruments $80 \mathrm{~mm}^{2} \mathrm{X}$-Max energy dispersive X-ray spectroscopy (EDS) detector and the AZtec software suite. In order to characterise the morphology of the various phases, bright-field imaging was undertaken on $\emptyset 3 \mathrm{~mm}$ electropolished discs of the TMP-L samples of both steels using a JEOL 2011 transmission electron microscope operating at $200 \mathrm{kV}$.

The volume fraction of the RA was estimated from X-ray diffraction (XRD) conducted on the TD-ND plane using the direct comparison method for $2 \theta=60-100^{\circ}$ [36] and integrating the intensity 
of the $(220)_{\gamma},(311)_{\gamma},(200)_{\alpha}$ and $(220)_{\alpha}$ peaks. The carbon content (wt.\%) in the RA was calculated as follows [37]:

$$
a_{\gamma}=\left[0.363067+\frac{0.0783}{1+0.2151\left(\frac{100}{\mathrm{C}}-1\right)}\right]+\left[25.92-\frac{51}{1+0.2151\left(\frac{100}{\mathrm{C}}-1\right)}\right] 10^{-6}(T-727)
$$

where $a_{\gamma}$ is the RA lattice parameter and $T$ is temperature $\left({ }^{\circ} \mathrm{C}\right)$.

Tensile dog-bones were wire-cut according to: (i) the sub-size ASTM-E8M standard [38] for the TMP-S, TMP-L and TMP-LG samples (Fig. 1c) and, (ii) the EN 10002 (Type 2) standard [39] for the IA-G samples (Fig. 1d). The use of a sub-size sample geometry was necessary for all TMP conditions due to the initial sample size limitations for thermo-mechanical processing on the Gleeble TMP simulator. Uniaxial tensile testing was conducted on a minimum of two dog-bone samples per condition at a constant strain rate of $4.5 \times 10^{-4}$ using: (i) an in-house modified 5kN Kammrath and Weiss GmbH tensile stage for all TMP samples at UOW and, (ii) a $50 \mathrm{kN}$ Instron 5569 screw-driven tensile machine for the IA-G samples at GIFT-POSTECH.

The yield strength (YS) is defined as the $0.2 \%$ offset proof stress or the point after Lüders banding is completed in the case of continuous and discontinuous yielding, respectively. Thereafter, the work hardening rate $\Theta=d \sigma / d \varepsilon$ and the strain hardening exponent (n-value) were calculated from the true stress and true strain curves [40]. The strain hardening exponent is an indication of the uniformity of strain distribution during forming operation such that the $\mathrm{n}$ value increases with greater thinning resistance during forming operations. The instantaneous strain hardening exponent is independent of the any power law and can be defined as $\mathrm{n}=[(\varepsilon / \sigma) \cdot \Theta][41]$

\section{Results}

The microstructures and mechanical properties of the base and Nb-Ti steels after the TMP-S, TMP-L, TMP-LG and IA-G schedules are presented in Figs. 3-8 and are discussed concomitantly as per their relevance. Due to the rather significant variation in the tensile sample geometries of the TMP and IA-G samples, the comparison of their mechanical properties is limited to only discussing their overall trends in terms of yielding (continuous versus discontinuous) and work hardening behaviour.

\subsection{The effect of composition on the microstructure and mechanical properties after the TMP-S schedule}

The microstructures of the base and Nb-Ti steels after the TMP-S schedule are shown in Figs. $3 \mathrm{a}, 3 \mathrm{~b}, 4 \mathrm{a}$ and $4 \mathrm{~b}$. In both steels, the microstructure consists predominantly of $\sim 45-48 \%$ polygonal ferrite (PF) and $\sim 35-40 \%$ bainite (B); with the remainder comprising the austenite and the martensite phases. The PF and bainite phases appear as light and dark grey after nital etching (Figs. 3a and 4a). Alternatively, the PF, bainite, austenite and martensite phases appear as light blue/brown, dark brown, white and black after colour etching, respectively (Figs. $3 \mathrm{~b}$ and $4 \mathrm{~b}$ ). 
PF tends to be of approximately equiaxed shape with $12 \pm 8 \mu \mathrm{m}$ and $10 \pm 6 \mu \mathrm{m}$ grain size (Table 2) for the base and Nb-Ti steels, respectively. The bainite lath thickness ranges between 0.5 to $1 \mu \mathrm{m}$ such that they are slightly coarser in the base steel compared to the Nb-Ti steel.

The $\sim 7 \%$ volume fraction of the RA phase was similar in both, the base and $\mathrm{Nb}$-Ti steels. The $\mathrm{RA}$ is present as blocky grains between the PF grains or at the interface between the PF and bainite or as fine layers between the BF laths. In both steels, the RA grains are $\sim 0.1$ to $0.3 \mu \mathrm{m}$ thick* such that they are slightly coarser in the base steel compared to the Nb-Ti steel. The majority of the martensite phase was found between PF grains and at the interface of the PF and bainite.

Both steels exhibit continuous yielding and smooth work hardening curves after the TMP-S treatment (Figs. 5 a-d). While the base steel recorded yield and ultimate tensile (UTS) strengths of $491 \pm 35 \mathrm{MPa}$ and 745 $\pm 6 \mathrm{MPa}$, respectively, the $\mathrm{Nb}$-Ti steel returned an YS $=474 \mathrm{MPa}$ and a UTS 782 MPa. In both steels, the uniform (UE) and total (TE) elongations were similar at $\sim 20 \%$ and $29 \%$, respectively. As seen in Fig. 5e, the TMP-S base steel reached a maximum n-value of 0.19 at a higher strain of $\sim 0.06$, fluctuated around this value until $\sim 0.14$ strain and then slightly declined to $\mathrm{n} \sim 0.18$ at 0.17 strain. In the TMP-S Ni-Ti steel (Fig. 5 f), a maximum n-value of $\sim 0.24$ was reached at a higher strain of $\sim 0.1$ and remained steady until it declined slightly to $\mathrm{n} \sim 0.22$ at 0.15 strain, followed by a further decline to $\mathrm{n} \sim 0.18$ at 0.18 strain.

\subsection{The effect of extended coiling time on the microstructure and mechanical properties}

The microstructures of the base and Nb-Ti steels after the long coiling time TMP-L schedule (Figs. 3c, 3d, 4c and 4d) are similar to those after TMP-S. The values of the volume fractions and the grain size of the ferrite phase after TMP-L remained similar to those obtained after the TMP-S treatment. As shown in the TEM micrographs (Fig. 6), two bainite morphologies were observed after TMP-L comprising fine lathes of bainitic ferrite (BF) and plates of granular bainite (GB).

In stark comparison to the TMP-S schedule, the TMP-L treatment showed that the volume fraction of the RA phase had decreased to $\sim 4 \pm 1 \%$ in the base steel and increased to $\sim 13 \%$ in the $\mathrm{Nb}$ - $\mathrm{Ti}$ steel as a direct result of microalloying (Table 2). Based on the micrographs after colour etching, the fraction of martensite was also slightly higher in the base steel compared to the Nb-Ti steel (Figs. 3d and $4 \mathrm{~d})$.

The EDS analysis of the precipitates in the TMP-L base steel revealed the presence of 100-200 $\mathrm{nm}(\mathrm{Al}, \mathrm{Si})(\mathrm{N}, \mathrm{O})$ and $(\mathrm{Mn}, \mathrm{Cu}) \mathrm{S}$ particles that were randomly scattered throughout the sample volume (Fig. 7a). In the TMP-L Nb-Ti steel (Fig. 7b), three major types of precipitates were observed: (i) 60$150 \mathrm{~nm}$ sized (Ti,Nb)(C,N), (ii) <100 nm Nb(C,N) and, (iii) >40 nm NbC (Figs. 7e-g).

The representative stress-strain, work hardening and instant-n curves are shown in Fig. 5 while the average data is given in Table 2. After the TMP-L treatment, the average yield (YS) and

\footnotetext{
${ }^{*}$ These measurements were undertaken using a combination of secondary electron and bright field imaging via scanning and transmission microscopy, respectively.
} 
ultimate tensile (UTS) strengths are $445 \pm 44 \mathrm{MPa}$ and $722 \pm 34 \mathrm{MPa}$ for the base steel and $476 \pm 7 \mathrm{MPa}$ and $749 \pm 20 \mathrm{MPa}$ for the Nb-Ti steel, respectively. The uniform and total elongations are $15 \%$ and $25 \%$ for the base steel and $18 \%$ and $29 \%$ for the $\mathrm{Nb}$-Ti steel, respectively. The base steel exhibits continuous yielding behavior which returns a smooth work hardening curve and instantaneous $\mathrm{n}$ values with a maximum of 0.2 at 0.05 strain followed by a gradual decrease to 0.15 at $\sim 0.15$ strain. On the other hand, the TMP-L Nb-Ti steel shows slight discontinuous yielding such that the work hardening curve steeply declines up to 0.01 strain and has a local maxima at 0.02 strain. The n-value reaches a maximum of 0.24 between strains of $0.05-0.08$ followed by a gradual decrease to $\mathrm{n} \sim 0.18$ at 0.17 strain.

\subsection{The effect of galvanising after TMP-L on the microstructure and mechanical properties}

Figs. $3 \mathrm{e}, 3 \mathrm{f}, 4 \mathrm{e}$ and $4 \mathrm{f}$ show the microstructure of the samples after the galvanising TMP-LG schedule. In the base and $\mathrm{Nb}$-Ti steels, colour etching returned more martensite (black areas) and a small number of white grains of the RA phase. These results were confirmed via XRD which also showed that the volume fraction of RA had decreased from $4 \pm 1 \%$ and $13 \pm 0 \%$ after TMP-L to $2 \pm 1 \%$ and $6 \pm 4 \%$ after TMP-LG in the base and Nb-Ti steels, respectively (Table 2 ). In addition to (Ti,Nb)(C,N) and $\mathrm{Nb}(\mathrm{C}, \mathrm{N})$ particles observed in the TMP-L Nb-Ti steel, the formation of $\mathrm{Fe}_{3} \mathrm{C}$ particles (Fig. 7h, 7i) was detected in this steel after galvanising (TMP-LG).

The tensile test results (Figs. $5 \mathrm{a}$ and $\mathrm{b}$ ) show that the base steel underwent continuous yielding whereas the Nb-Ti steel depicted Lüders banding. Compared to the TMP-L samples, the TMP-LG samples recorded an increase in the YS of both steels (from $445 \pm 44$ to $476 \pm 6 \mathrm{MPa}$ for the base steel and from $476 \pm 7$ to $499 \pm 6 \mathrm{MPa}$ for Nb-Ti steel) while the UTS was found to have reduced from $722 \pm 34$ to $699 \pm 9 \mathrm{MPa}$ in the base steel and from $749 \pm 20$ to $685 \pm 32 \mathrm{MPa}$ in the Nb-Ti steel. Correspondingly, the uniform and total elongations in both the steels was also seen to reduce from $15-18 \%$ and $25-29 \%$ after TMP-L to $12-13 \%$ and $24-26 \%$ after TMP-G treatment, respectively.

The work hardening and instantaneous n-value curves (Figs. 5c-5f) show marked differences between the TMP-L and the TMP-LG schedules. In the TMP-LG base steel, the n-value declines from a strain of $\sim 0.06$ at a faster rate and reaches its lowest value of 0.11 at $\sim 0.11$ strain. In the TMP-LG NbTi steel, the $\mathrm{n}$-value fluctuates around the maximum n-value of $\sim 0.195$ between strains of 0.05-0.12. Overall, the n-curve for the Nb-Ti steel after TMP-LG records its lowest values compared to all other schedules.

\subsection{The effect of intercritical annealing on the microstructure and mechanical properties}

The secondary electron images of the microstructures after TMP-S and IA-G are shown in Figs. 8a, $8 \mathrm{~b}$ and 8c, 8d for the base (Figs. 8a, 8c) and Nb-Ti (Figs. 8b, 8d) steels, respectively. It is obvious that the two processing techniques result in completely different microstructures. While the images record the similar volume fractions of PF for both steels, the PF grain size after TMP-S is 
approximately twice that after the IA-G schedule (Table 2). After TMP-S, the austenite, bainite and martensite phases exist within banded areas whereas after the IA-G treatment, the same phases are equiaxed and interspersed between the PF grains. Compared to the TMP-S condition, both steels after IA-G possess slightly larger volume fractions of RA with lower carbon content.

The tensile curves after the IA-G schedules record discontinuous yielding in both steels (Figs. $5 \mathrm{a}$ and $5 \mathrm{~b}$ ). Compared to the TMP-S condition, the YS after IA-G is $\sim 131$ and $\sim 36 \mathrm{MPa}$ lower in the base and $\mathrm{Nb}$-Ti steels, respectively (Table 2). In contrast, if the UTS values after the two schedules are compared, the values are $\sim 42 \mathrm{MPa}$ higher in the base steel and $\sim 72 \mathrm{MPa}$ lower in the Nb-Ti steel. In the IA-G samples, a visible change in the gradient of the work hardening curves occurs at $\sim 0.016$ strain for the base steel and $\sim 0.03$ strain for the $\mathrm{Nb}$-Ti steel (Figs. 5c, $5 \mathrm{~d}$ ). In contrast to all other conditions, further changed in the work hardening rate occurs at the strains of $\sim 0.14$ and $\sim 0.153$ in the Nb-Ti IA-G steel. In both steels, the shape of the instantaneous n-value curve is very different after the IA-G schedules (Figs. 5e, 5f). A rather narrow peak with maximum n-values of $\sim 0.39$ and $\sim 0.34$ at 0.03 and 0.035 strains is followed by sharp declines to $\sim 0.175$ and $\sim 0.19$ at 0.175 and 0.13 strains for the base and $\mathrm{Nb}$-Ti steels, respectively.

\section{Discussion}

\subsection{The effect of processing parameters on the microstructure-mechanical property relationships}

It should be kept in mind that in the TMP-S, TMP-L and TMP-LG schedules the parameters for austenisation and the formation of PF were kept constant; which also resulted in the formation of approximately similar (50\%) volume fractions of PF. The isothermal bainite transformation temperature $\left(=\right.$ the coiling temperature, $\mathrm{T}_{\mathrm{C}}$ ) during simulated coiling was also kept similar (465-470 ${ }^{\circ} \mathrm{C}$ ) such that only the coiling time $\left(\mathrm{t}_{\mathrm{c}}\right)$ was varied between $125 \mathrm{~s}$ and $1200 \mathrm{~s}$ in the case of TMP-S and TMP-L, respectively. During the TMP-LG schedule, an additional galvanising treatment was employed only after the TMP-L treatment was completed.

The above variations in the processing schedules have a pronounced effect on the microstructure and the mechanical properties of the two steels (Table 2). For example, the YS of the base steel decreases with longer coiling time followed by an increase in strength after the TMP-LG treatment. On the other hand, the UTS values decrease with increasing coiling time in both steels such that an even further lowering of the UTS occurred after the TMP-LG schedule. With respect to ductility, both steels record a decrease in their UE and TE values with higher coiling times. In this case, the base steel was more severely affected with longer coiling times resulting in even smaller ductility values. From the above, it is clear that longer coiling times leads to an overall deterioration of the strengthductility balance in both steels.

Although the PF grain size in the base steel after TMP-S could be regarded as only slightly coarser $(12 \pm 8 \mu \mathrm{m})$ than the Nb-Ti steel $(10 \pm 6 \mu \mathrm{m})$, the YS of the base steel after TMP-S is higher compared to the $\mathrm{Nb}$-Ti steel. This disparity could be related to the complexity of the microstructure in 
our multiphase steel and the dominant effect of other microstructural parameters such as the morphology of the bainite. The base steel consists predominantly of fine $0.35 \mu \mathrm{m}$ sized plates of granular bainite (GB). On the other hand, the Nb-Ti steel mostly comprises significantly coarse $0.81 \mu \mathrm{m}$ sized bainitic ferrite (BF) laths. Thus, it is entirely plausible that the variation in the dislocation mean free path between GB and BF is primarily responsible for the differences in the macroscopic mechanical properties of the two steels after the TMP-S treatment. Generally speaking, the combination of strength and elongation after the TMP-S and TMP-L schedules is slightly better in the $\mathrm{Nb}$-Ti steel compared to the base steel. This is ascribed to the finer microstructure of the Nb-Ti steel and the additional solid solution and/or precipitation strengthening via alloying with $\mathrm{Nb}$ and Ti. While the above is in agreement with previous reports for high $\mathrm{Si}$, Nb-containing steels [42], other variations between the two steels are detailed below.

During the longer coiling times, the formation of bainite is accompanied by the carbon enrichment of the RA which is located in-between bainitic ferrite laths or plates. If bainite transformation is completed with the steel remaining at a high temperature, the next stage of phase transformation is initiated wherein: (i) the carbon-enriched austenite starts to decompose with the formation of the ferrite phase and carbides and, (ii) in the remainder BF which is supersaturated with carbon, the segregation of carbon to dislocations and/or the formation of fine carbides takes place. The latter observations were noted previously during the bake hardening of high-Si TRIP steels [43].

It is clear that the bainite transformation was completed sometime between $125 \mathrm{~s}$ and $1200 \mathrm{~s}$ in the base steel, whereas this amount of transformation time was insufficient for the Nb-Ti steel. This is ascertained by the fact that the volume fraction of the RA decreases between the TMP-S and TMP-L treatments in the base steel whereas it continues to increase in the Nb-Ti steel (Table 2). Specific to the $\mathrm{Nb}$-Ti steel, the significance of the interaction between the other phases in dictating the overall mechanical response is also highlighted here. The increase in the RA volume fraction helps the Nb-Ti steel to maintain its YS and TE levels while reducing the rate of decrease in the UTS and UE values after the TMP-S and TMP-L schedules.

However, the effect of a nearly doubled volume fraction of the RA phase content after the TMPL schedules in the Nb-Ti steel underlines the more crucial effect of the alloying elements on the kinetics of the bainitic transformation. In the presence of $\mathrm{Nb}$, the bainitic transformation is more sluggish as the prior austenite grain size is reduced [16] and this results in a low volume fraction of stable austenite; i.e.- a higher volume fraction of untransformed austenite with lower chemical stability such that it readily transforms to martensite upon tensile deformation.

During the TMP-LG industrial galvanising schedule, a further decomposition of the RA takes place; as evidenced by the low volume fractions of RA in both steels (Table 2). While both steels recorded increases in yield strength between the TMP-L and TMP-LG conditions, the UTS, UE and TE values were reduced. Since a larger volume fraction of RA pre-existed in the TMP-L Nb-Ti steel, the degradation in its mechanical properties after the TMP-LG schedule is more severe than that in the 
base steel. In addition, while carbon segregates to dislocations and grain boundaries, it also forms carbides in the PF and BF phases after the TMP-L and TMP-LG treatments (Fig. 7b-7h). In particular, carbon segregation could take place in the areas of high dislocation density surrounding the martensite crystals that are newly formed upon quenching from the coiling temperature [43]. The small amount of martensite formed on cooling will also undergo a typical tempering process; with the formation of intermediate carbides or cementite during the TMP-LG schedule [44,45]. Thus, all these changes will contribute to the interaction of dislocations with carbon atoms and with precipitates during tensile testing such that they will result in an increase in YS and a reduction in ductility values.

An important difference in the stress-strain curves between the base and $\mathrm{Nb}$-Ti steels is that the former shows continuous yielding up to the TMP-LG schedule (Fig. 5a) whereas the latter presents with discontinuous yielding after the TMP-L and TMP-LG treatments (Fig. 5b). Similar strain hardening behavior was observed for dual-phase and IA TRIP steels after pre-straining and bake hardening [46,42]. Discontinuous yielding via Lüders banding is typically evidence of dislocations locking either by Cottrell atmospheres and/or by fine precipitates and their subsequent unlocking or, the formation of new mobile dislocations [40].

As reported previously, new dislocations are generated in the ferrite phase either: (i) upon cooling after isothermal holding at $470{ }^{\circ} \mathrm{C}$ due to the volume change associated with the phase transformation of the unstable austenite to martensite or, (ii) during tensile testing when soft ferrite regions are adjacent to hard martensite or austenite crystals $[43,46]$. Since the Nb-Ti steel consistently returns higher volume fractions of RA than the base steel for corresponding conditions (Table 4), it could be expected that a higher number of mobile dislocations is generated in this steel as a result of the austenite to martensite transformation during straining. This could be one of the contributing factors to the pronounced yield point phenomena observed in the Nb-Ti steel after TMP-L and TMP-LG processing.

In addition, the difference in the yielding behaviors between the base and $\mathrm{Nb}$-Ti steel can be further explained by considering the interaction of carbon with dislocations and the ability of the $\mathrm{Nb}$, $\mathrm{Ti}$ and Fe atoms to form carbides. In the base steel, the interaction of carbon atoms with dislocations would be preferred mechanism as the binding energy between dislocations and carbon is $0.75 \mathrm{eV}$; which in turn, is higher than the $0.5 \mathrm{eV}$ binding energy between the $\mathrm{Fe}$ and $\mathrm{C}$ atoms to form $\mathrm{Fe}_{3} \mathrm{C}$ [47]. On the other hand, and to serve as an example, the binding energy between the $\mathrm{Nb}$ and $\mathrm{C}$ atoms to form $\mathrm{NbC}$ is $2.3 \mathrm{eV}$ [42]. Thus, it could be speculated that the amount of $\mathrm{C}$ available in the base steel is sufficient to form saturated Cottrell atmospheres at dislocations. Contrarily, in the Nb-Ti steel, some of the carbon would be used up to form Nb-Ti carbides; thus leading to the formation of much weaker Cottrell atmospheres that are more easily unlocked on loading.

The appearance of Lüders strain in IA TRIP steels has also been previously attributed to the localisation of deformation within the ferrite phase; with whom the static ageing of solute carbon is also associated $[48,49]$. Thus, in the case of $\mathrm{Nb}$-Ti steel, it can also be said that the discontinuous 
yielding behavior is the combined effect of the finer ferrite grain size (leading to a localisation of the deformation within this phase) [50] and the ageing that occurs during the TMP-LG schedule.

To this end, the work hardening behavior of the steels was analysed using the modified C-J analysis $[28,29]$. Representative $\ln (\mathrm{d} \sigma / \mathrm{d} \varepsilon)$ versus $\ln (\sigma)$ plots are shown in Fig. 9 with the results from fitting presented in Table 3. Since the modified C-J analysis was unable to fit the flow curve over the entire uniform strain range region, the work hardening curves were divided into a maximum of three stages and different m-values were determined for each work hardening stage (Fig. 9).

If Fig. 9 is used as representative example, the behaviour of the $\mathrm{Nb}$-Ti steel during each of the three stages is seen to vary rather significantly after the TMP-S (Fig. 9a) and TMP-L (Fig. 9b) schedules. This can be ascribed to the amount and the morphology of phase constituents; which in turn, control the behaviour during the various stages of work hardening. During Stage 1, the deformation of the soft ferrite phase leads to an accumulation of mobile dislocations in the regions near the interface between the ferrite and the harder phases such as RA and martensite. In Stage 2, the RA transforms to martensite due to the accumulation of strain energy in the RA phase. During Stage 3, the deformation of ferrite and martensite continues while the work hardening rate continuously decreases.

In Stage 1, the rate of dislocation accumulation is strongly linked to the ferrite grain size. In this regard, the influence of the finer ferrite grain size lead to the smallest $\mathrm{m}_{1}$-values being recorded after the IA-G schedule in both steels. Previous reports have also claimed that high $\mathrm{m}_{1}$-values are related to the larger volume fraction of martensite present in the initial microstructure [29]. However, the influence of this factor is not clear from the present study as the highest the $\mathrm{m}_{1}$-values were returned after the TMP-L and TMP-LG schedules for the base and Nb-Ti steels, respectively (Table 3).

Stage 2 behaviour that is more similar to dual phase steels [10] is returned after the TMP-S, TMP-L and TMP-LG schedules in the base steel and after the TMP-S schedule in the Nb-Ti steel (Fig. 9a). On the other hand, and as depicted in Fig. 9b, Stage 2 behaviour that is typically associated with the TRIP effect was noted after the TMP-L and TMP-LG treatments in the Nb-Ti steel. During Stage 2, the accumulation of strain energy in the RA phase occurs several times over and results in a gradual transformation of the RA to martensite. In turn, the phase transformation increases the work hardening rate (leading to a slope change) by inhibiting the dislocation glide process. Consequently, the differences in the behavior and slope of the Stage 2 hardening in the studied steels could be explained by rate of transformation of the RA during the uniform straining. This above phenomenon has been previously proven by observing areas of high dislocation density surrounding the newly formed martensite crystals [43].

The differences in the shape of strain hardening exponent curves over the period of uniform elongation allude to variations in the rate of strain-induced austenite transformation (Figs. 5e, 5f). In general, more gradual increases and sustained n-values are correlated with a slower transformation of the RA to martensite over longer strain ranges such that the TRIP effect then tends to contribute more 
significantly towards extending the overall ductility of the steel. It should be noted that the authors had previously reported on the stability of RA during the uniaxial tensile testing of the base and $\mathrm{Nb}-\mathrm{Ti}$ steels after TMP-L processing [51]. In that study, Electron Back-Scattering Diffraction was used to track the changes in the area fraction of the RA up to the UTS value. While the base steel recorded a more gradual change in the area fraction of RA from 5\% (initial, $\varepsilon=0 \%$ ) to $1.2 \%$ (at UTS, $\varepsilon=15 \%$ ), the $\mathrm{Nb}$-Ti steel exhibited a more rapid transformation of the RA fraction from $9.4 \%$ (initial, $\varepsilon=0 \%$ ) to $1.4 \%$ (at UTS, $\varepsilon=18 \%$ ).

To this end, the following examples highlight the importance of both, the volume fraction and the carbon content of the RA phase in dictating the overall shape of the strain hardening exponent curves of both steels. In the base steel, the gradual transformation of the highest amount of the RA with the highest carbon content after the TMP-S schedule was responsible for the observed n-value behavior and good combination of strength and ductility. In the case of the Nb-Ti steel, the most gradual transformation of the RA during tensile straining was obtained after the TMP-S schedule. This could be due to the carbon content of the RA after TMP-S being slightly higher than that obtained after the TMP-L schedule when the highest volume fraction of the RA was returned. Since the volume fraction and the carbon content (chemical stability) of the RA were the lowest after the TMP-LG treatment, both steels presented with sharp rises in the strain hardening exponent which in turn, is correlated with the rapid transformation of the RA to martensite during the early stages of straining. It should be noted that while the effect of chemical stability was used to explain the overall stability of the RA, the difference in the carbon content after TMP-S and TM-L is not significant. Thus, the overall stability of the RA could also be affected by other parameters such as the mechanical stability of RA.

\subsection{Comparison of thermo-mechanically processed and intercritically annealed steels}

Although both the steels in the TMP-S and IA-G conditions contained $\sim 50 \%$ PF in the microstructure, the morphology and distribution of the phases varied significantly. During the TMP-S treatment, the formation of the PF grains takes place predominantly at the boundaries of the elongated prior austenite grains upon cooling at $1 \mathrm{Ks}^{-1}$ such that the process is interrupted when cooling is further accelerated to $20 \mathrm{Ks}^{-1}$. As a direct result of the accelerated cooling, the bainite transformation then occurs in-between the rows of the PF grains during the isothermal holding step $\left(\mathrm{T}_{\mathrm{C}}=465{ }^{\circ} \mathrm{C}\right.$ for $\mathrm{t}_{\mathrm{c}}$ $=125 \mathrm{~s}$ and/or $1200 \mathrm{~s}$ ). Consequently, the majority of the RA and martensite crystals are located within the bainite regions. Due to such clearly developed directionality in the microstructure, significant anisotropy in the mechanical properties could be expected between the longitudinal and transverse directions of the samples.

On the other hand, the microstructure in the IA-G steels first developed as the reverse transformation of the cold rolled microstructure into a mixture of austenite and ferrite such that the subsequent formation of bainite occurred during isothermal holding. This resulted in a more homogeneous distribution of equiaxed PF grains and bainitic areas. 
The main distinctive feature of the IA-G stress-strain curves of both steels is the rather pronounced yield point elongation and a continuous reduction in n-value with greater tensile strain. These results are similar to the behavior of tempered dual-phase steels [52] and of C-Mn-Si steels subjected to the quenching and partitioning treatment [53]. The yield point phenomenon indicates that during IA-G treatment, some dislocation pinning by carbon atoms took place in the ferrite phase and that based on the SEM observations, small carbide particles were also present in the areas of decomposed austenite (Fig. 8d inset). As discussed previously, the finer ferrite grain size combined with the ageing processes that take place during the IA-G schedule $[49,50]$ could be responsible for the pronounced Lüders strain and the increase in the Lüders elongation.

In both IA-G steels, the work hardening behavior during Stage 2 was similar to that of TRIP steels (Fig. 9b), whereas in the TMP-S steels it was similar to the one of dual-phase steels (Fig. 9a), as discussed in Section 4.1. On the other hand, the presence of a single maximum n-value early on the tensile test in both IA-G steels indicates that a large amount of the RA transformed to martensite upon initial straining. This can be correlated to the fact that the RA is less stable in the IA-G steels compared to the TMP-S steels. This lower stability could be due to several factors among which slightly lower carbon content of the RA in IA-G steels and also the presence of refined and rigid bainite plates which could assist in an earlier load transfer and the transformation to martensite of adjacent RA layers [54].

\section{Conclusions}

The microstructure-property relationships in a base low $\mathrm{Si}$, high Al TRIP steel and one with $0.03 \mathrm{Nb}$ and $0.02 \mathrm{Ti}$ (wt.\%) additions were analysed after different thermo-mechanical processing schedules such that:

1. Thermo-mechanical processing of the base steel with a short coiling time of $125 \mathrm{~s}$ at $470^{\circ} \mathrm{C}$ resulted in the highest amount of the retained austenite phase and the best combination of mechanical strength and elongation. All thermo-mechanically processed base steel samples recorded continuous yielding behavior.

2. The addition of $\mathrm{Nb}$ and Ti refined the final microstructure of the steel after thermo-mechanical processing but led to an increase in the time required for the development of a high volume fraction of the stable retained austenite phase. Compared to the base steel, the strengthductility balance in the $\mathrm{Nb}$-Ti steel was slightly improved due to a combination of microstructure refinement, a higher volume fraction of the RA and precipitation strengthening. The $\mathrm{Nb}$-Ti steel exhibited discontinuous yielding behavior after thermo-mechanical processing when a long coiling time of $1200 \mathrm{~s}$ was undertaken.

3. The intercritically annealed samples of the base and $\mathrm{Nb}$-Ti steels showed discontinuous yielding with long Lüders elongation. A steep reduction in the instantaneous n-value from its maximum at a small value of tensile strain was noted. This was explained by the refinement of the polygonal ferrite grains and the ageing processes that take place during galvanising. 
4. The modified C-J analysis showed three stages of work hardening in the studied steels. However, the Stage 2 behavior was found to differ with the adopted processing schedule and was associated with the different rates of the RA transformation.

\section{Acknowledgments}

The authors are grateful to POSCO for providing the base and Ni-Ti steels. This work was funded in part by the Engineering Materials Institute at UOW. The SEM/EDS work was undertaken on a JEOL JSM-7001F FEG-SEM that was funded by the ARC LIEF grant LE0882613. One of the authors (F. Alharbi) is grateful to the Saudi Basic Industries Corporation (SABIC) for the financial support towards his PhD studies.

\section{References}

1. Zackay VF, Parker ER, Fahr D et al. (1967) The enhancement of ductility in high-strength steels. ASM Trans Q 60 (2):252-259.

2. Jacques P, Eberle K, Harlet $P$ et al. (1998) development and characterisatin of a cold-rolled lowSilicon TRIP-Assisted Multiphase Steel; a New Opportunitiy for the Automotive Steel Industry. 40th MWSP Conf Proc, ISS 239, 1998. pp 239-250

3. De Cooman BC (2004) Structure-properties relationship in TRIP steels containing carbide-free bainite. Curr Opin Solid State Mat Sci 8 (3-4):285-303.

4. Pereloma EV, Timokhina IB, Hilditch TB et al. (2010) Effect of manufacturing process on the final properties of advanced high strength steels for automotive applications. Mater Sci Forum 638642:148-153.

5. Matsumura O, Sakuma Y, Takechi H (1987) TRIP and its kinetic aspects in austempered 0.4 C-1.5 Si$0.8 \mathrm{Mn}$ steel. Scr Metall 21 (10):1301-1306.

6. Sugimoto K, Usui N, Kobayashi M et al. (1992) Effects of volume fraction and stability of retained austenite on ductility of TRIP-aided dual-phase steels. ISIJ Int 32 (12):1311-1318.

7. Lee YY, Kwak JH, Kim JS et al. (2010) Development of a Robust TRIP800 concept for GI/GA automotive applications. Mater Sci Forum 654 - 656:274-277.

8. Jun HJ, Park SH, Choi SD et al. (2004) Decomposition of retained austenite during coiling process of hot rolled TRIP-aided steels. Mater Sci Eng A 379 (1):204-209.

9. Takahashi M, Bhadeshia H (1991) A model for the microstructure of some advanced bainitic steels. Mater Trans, JIM 32 (8):689-696.

10. Jacques PJ, Delannay F, Ladriere J (2001) On the influence of interactions between phases on the mechanical stability of retained austenite in transformation-induced plasticity multiphase steels. Metall Mater Trans A 32 (11):2759-2768.

11. Timokhina IB, Hodgson PD, Pereloma EV (2004) Effect of microstructure on the stability of retained austenite in transformation-induced-plasticity steels. Metall Mater Trans A 35A (8):23312341.

12. Barbe L, Verbeken K, Wettinck E (2006) Effect of the addition of $P$ on the mechanical properties of low alloyed TRIP steels. ISIJ Int 46 (8):1251-1257.

13. Bleck W, Frehn A, Kechagias E et al. (2003) Control of microstructure in TRIP steels by niobium. Mater Sci Forum 426-432:43-48.

14. Bai DQ, Di Chiro A, Yue S (1998) Stability of retained austenite in a Nb microalloyed Mn-Si TRIP steel. Mater Sci Forum (Switzerland) 284-286:253-260.

15. Sugimoto K, Muramatsu T, Hashimoto S et al. (2006) Formability of Nb bearing ultra high-strength TRIP-aided sheet steels. J Mater Process Technol 177 (1-3):390-395.

16. Bleck W, Hulka K, Papamentellos K (1998) Effect of niobium on the mechanical properties of TRIP steels. Mater Sci Forum 284 - 286:327-334. 
17. Samek L, Moor ED, Penning J et al. (2006) Influence of alloying elements on the kinetics of straininduced martensitic nucleation in low-alloy, multiphase high-strength steels. Metall Mater Trans A 37A (1):109-124.

18. Li L, De Cooman BC, Wollants P et al. (2004) Effect of aluminum and silicon on transformation induced plasticity of the TRIP steel. Mater Sci Technol 20 (2):135-138.

19. Maki J, Mahieu J, De Cooman BC et al. (2003) Galvanisability of silicon free CMnAl TRIP steels. Mater Sci Technol 19 (1):125-131.

20. Li Z, Wu D (2008) Effects of hot deformation and subsequent austempering on mechanical properties of high silicon and low silicon TRIP steel. Mater Sci Technol 24 (2):168-176.

21. Hashimoto S, Ikeda S, Sugimoto K et al. (2004) Effects of $\mathrm{Nb}$ and Mo addition to $0.2 \% \mathrm{C}-1.5 \% \mathrm{Si}$ $1.5 \% \mathrm{Mn}$ steel on mechanical properties of hot rolled TRIP-aided steel sheets. ISIJ Int 44 (9):15901598.

22. Timokhina IB, Hodgson PD, Pereloma EV (2003) Effect of deformation schedule on the microstructure and mechanical properties of a thermomechanically processed C-Mn-Si transformation-induced plasticity steel. Metall Mater Trans A 34A (8):1599-1609.

23. Hollomon JH (1945) Tensile deformation. Trans AIME 162:268 -290.

24. Ludwik P (1909). Elemente der Technonogischen Mechanic, Springer-Verlag.

25. Voce E (1948) The relationship between stress and strain for homogeneous deformation. J Inst Met $74: 537-562$.

26. Swift HW (1952) Plastic Instability Under Plane Stress. J Mech Phys Solids 1 (1):1-18.

27. Ludwigson DC (1971) Modified stress-strain relation for FCC metals and alloys. Metall Trans 2 (10):2825-2828.

28. Tomita Y, Okabayashi K (1985) Tensile stress-strain analysis of cold worked metals and steels and dual-phase steels. Metall Mater Trans A 16 (5):865-872.

29. Kumar A, Singh SB, Ray KK (2008) Influence of bainite/martensite-content on the tensile properties of low carbon dual-phase steels. Mater Sci Eng A 474 (1-2):270-282.

30. Embury D, Bouaziz O (2010) Steel-based composites: driving forces and classifications. Annu Rev Mater Res 40:213-241.

31. Davut K, Zaefferer S (2012) The effect of size and shape of austenite grains on the mechanical properties of a low-alloyed TRIP steel. Steel Res Int 83 (6):584-589.

32. Chattopadhyay A, Subramanya Sarma V, Murty BS et al. (2009) Studies on hot rolled galvanized steel sheets: Effect of reheating on galvanizing. Surf Coat Technol 203 (22):3465-3471.

33. Bordignon L (2001) Galvanising of hot rolled strip. Galvatech'2001: 5 th International Conference on Zinc and Zinc Alloy Coated Steel Sheet, Bruxelles. pp 19-26

34. De AK, Speer JG, Matlock DK (2003) Color tint-etching for multiphase steels. Adv Mater Processes $161(2): 27-30$.

35. Parish CM (2003) Fundamental study of phase transformation in Si-Al TRIP steels. PhD diss, University of Pittsburgh.

36. Cullity BD, Stock SR (2001) Elements of X-ray diffraction. 3 edn. Prentice hall, Upper Saddle River,

37. Onink M, Brakman CM, Tichelaar FD et al. (1993) The lattice parameters of austenite and ferrite in

Fe-C alloys as functions of carbon concentration and temperature. Scr Mater 29 (8):1011-1016.

38. ASTM E8-M (1995) Standard test methods for tension testing of metallic materials. ASTM International.

39. EN 10002-1 (2001) Metallic materials-Tensile testing.

40. Dieter GE, Bacon D (1986) Mechanical metallurgy, vol 2. McGraw-Hill New York,

41. Brammar I, Harris D (1975) Production and properties of sheet steel and aluminum alloys for forming applications. J Aust Inst Met 20 (2):85-100.

42. Pereloma E, Russell K, Miller M et al. (2008) Effect of pre-straining and bake hardening on the microstructure of thermomechanically processed CMnSi TRIP steels with and without $\mathrm{Nb}$ and Mo additions. Scr Mater 58 (12):1078-1081.

43. Timokhina IB, Hodgson PD, Pereloma EV (2007) Transmission electron microscopy characterization of the bake-hardening behavior of transformation-induced plasticity and dual-phase steels. Metall Mater Trans A 38 (10):2442-2454.

44. Krauss G (2005) Steels: processing, structure, and performance. ASM International, Materials Park, Ohio, 
45. Pereloma E, Miller MK, Timokhina I (2008) On the decomposition of martensite during bake hardening of thermomechanically processed transformation-Induced plasticity steels. Metall Mater Trans A 39 (13):3210-3216.

46. Pereloma E, Beladi H, Zhang L et al. (2012) Understanding the behavior of advanced high-strength steels using atom probe tomography. Metall Mater Trans A 43 (11):3958-3971.

47. Cochardt A, Schoek G, Wiedersich H (1955) Interaction between dislocations and interstitial atoms in body-centered cubic metals. Acta Metall 3 (6):533-537.

48. Jung J, Kim H, De Cooman B (2010) Yielding behavior of Nb micro-alloyed C-Mn-Si TRIP steel studied by In-situ synchrotron X-ray diffraction. ISIJ Int 50 (4):620-629.

49. Jung J, Lee SJ, Kim S et al. (2011) Effect of Ti additions on micro-alloyed Nb TRIP steel. Steel Res Int 82 (7):857-865.

50. Tsuchida N, Tomota Y, Nagai K et al. (2006) A simple relationship between Luders elongation and work-hardening rate at lower yield stress. Scr Mater 54 (1):57-60.

51. Pereloma EV, Gazder AA, Timokhina I (2012) The transformation-induced plasticity effect and the stability of retained austenite in steels. In: R. Colás, G.E. Totten (eds) The Encyclopaedia of Iron, Steel and Their Alloys. Taylor and Francis, New York, Under review,

52. Moor ED, Lacroix S, Clarke AJ et al. (2008) Effect of retained austenite stabilized via quench and partitioning on the strain hardening of martensitic steels. Metall Mater Trans A 39 (11):2586-2595.

53. Moor ED, Speer JG, Matlock DK et al. (2011) Effect of carbon and manganese on the quenching and partitioning response of CMnSi steels. ISIJ Int 51 (1):137-144.

54. Tomota Y, Tokuda H, Adachi Y et al. (2004) Tensile behavior of TRIP-aided multi-phase steels studied by in situ neutron diffraction. Acta Mater 52 (20):5737-5745. 


\section{Figures list}

Figure 1: Schematic of the sample geometry and dimensions (a) before and (b) after thermomechanical processing. Tensile dog-bones (c) wire-cut from the RD/TD plane along the TD direction of the TMP-S, TMP-L and TMP-LG samples and, (d) of the IA-G samples.

Figure 2: Schematics of the thermo-mechanical processing schedules denoted as (a) TMP-S and TMP-L for short and long coiling times ( $t_{c}=125$ and $1200 \mathrm{~s}$ ), (b) TMP-LG where an additional galvanising treatment is undertaken after TMP-L and, (c) IA-G involving intercritical annealing - galvanising treatment. $\mathrm{T}_{\mathrm{FR}}=$ finish rolling temperature; $\mathrm{T}_{\mathrm{AC}}=$ start of accelerated cooling temperature, $\mathrm{T}_{\mathrm{C}}=$ coiling temperature; $\mathrm{T}_{\mathrm{IA}}=$ intercritical annealing temperature.

Figure 3: (a, c, e) Nital and (b, d, f) colour etched microstructures of the base steel after (a, b) TMP-S, (c, d) TMP-L and (e, f) and TMP-LG schedules. $\mathrm{PF}=$ polygonal ferrite; $\mathrm{BF}=$ bainitic ferrite; $\mathrm{M}=$ martensite and $\mathrm{RA}=$ retained austenite .

Figure 4: (a, c, e) Nital and (b, d, f) colour etched microstructures of the Nb-Ti steel after (a, b) TMP-S, (c, d) TMP-L and (e, f) and TMP-LG schedules.

Figure 5: The variation in $(a, b)$ the engineering stress versus strain, $(c, d)$ the work hardening rate versus true strain and, (e, f) the instantaneous n-value versus true strain in the $(a, c, e)$ base and $(b, d$, f) $\mathrm{Nb}$-Ti steels.

Figure 6: Representative bright field micrographs of the various bainitic morphologies seen in the base steel after the TMP-L schedule. $\mathrm{PF}=$ polygonal ferrite; $\mathrm{BF}=$ bainitic ferrite; $\mathrm{M}=$ martensite and $\mathrm{RA}=$ retained austenite.

Figure 7: Representative secondary electron micrographs of the (a) TMP-L base, (b) TMP-L Nb-Ti and, (c) TMP-LG Nb-Ti steels. (d-i) Example EDS spectra of (d) an $\mathrm{Al}(\mathrm{O}, \mathrm{N})+\mathrm{Cu}$ particle from the TMP-L base steel, (e) (Ti,Nb)(C,N), (f) $\mathrm{Nb}(\mathrm{C}, \mathrm{N})$ and (g) NbC particles from the TMP-L Nb-Ti steel, (h) $\mathrm{Fe}_{3} \mathrm{C}$ particles in and, (i) the matrix of the TMP-LG Nb-Ti steel. 
Figure 8: Representative secondary electron micrographs after (a, b) TMP-S and (c, d) IA-G processing of the $(a, c)$ base and (b, d) Nb-Ti steels. In (d), the inset shows the initial decomposition of the RA phase.

Figure 9: Representative work hardening behaviors shown using examples of $\mathrm{Nb}$-Ti steel after (a) TMP-S and (b) TMP-L schedules. Based on the modified C-J analysis, three distinct stages of work hardening can be seen. 


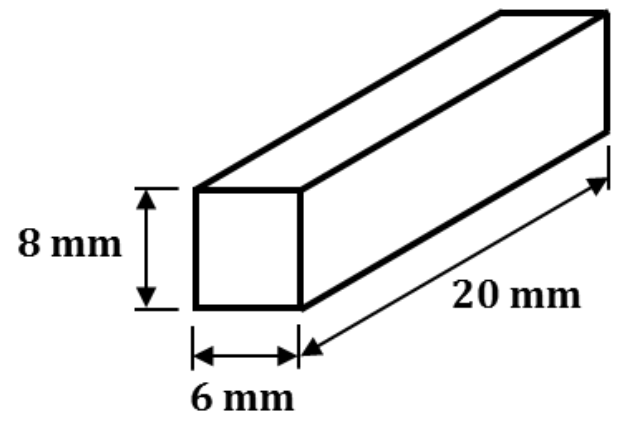

(a)

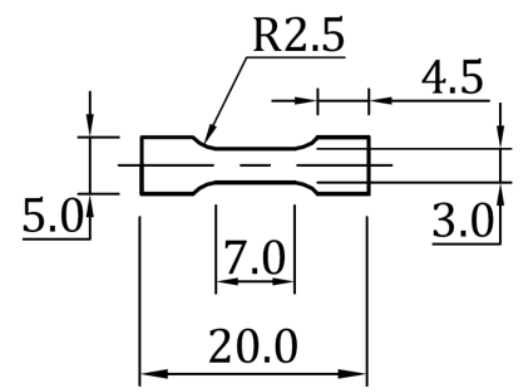

(c)
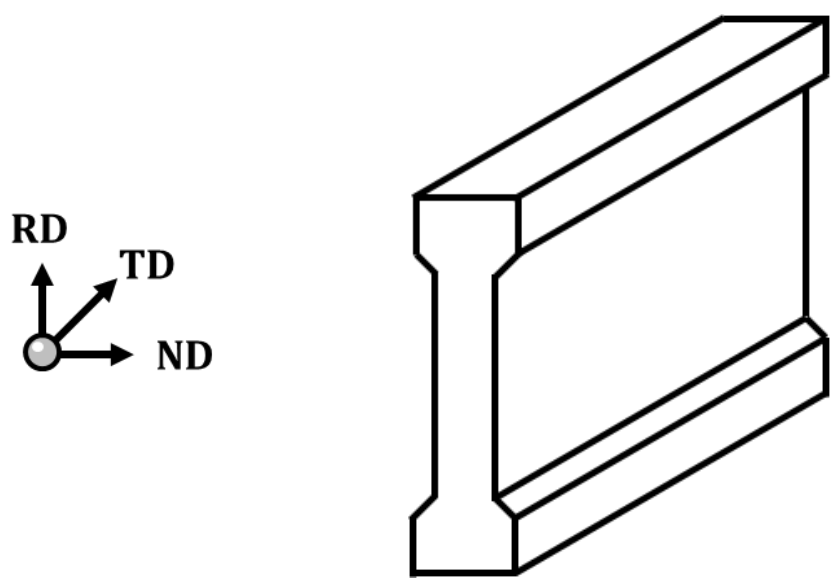

(b)

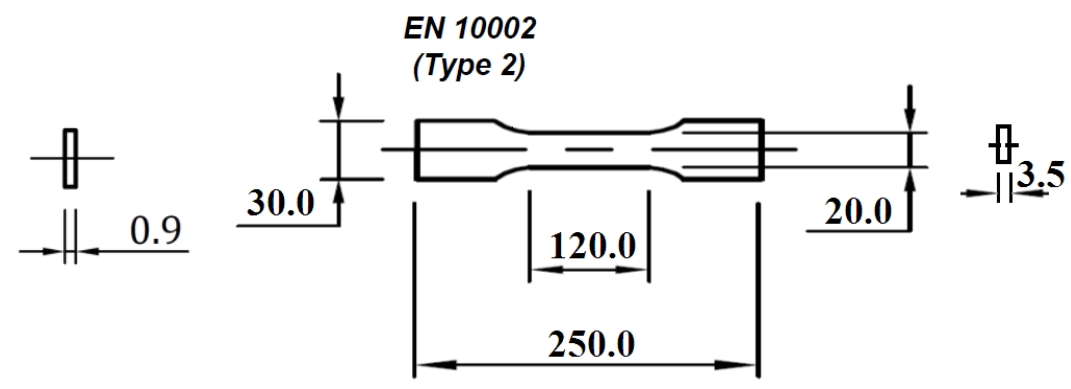

(d)

Figure 1: Schematic of the sample geometry and dimensions (a) before and (b) after thermomechanical processing. Tensile dog-bones (c) wire-cut from the RD/TD plane along the TD direction of the TMP-S, TMP-L and TMP-LG samples and, (d) of the IA-G samples. 


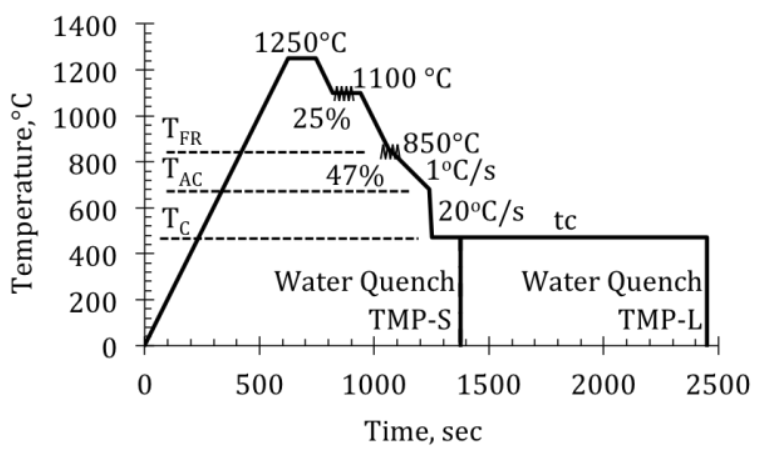

(a)

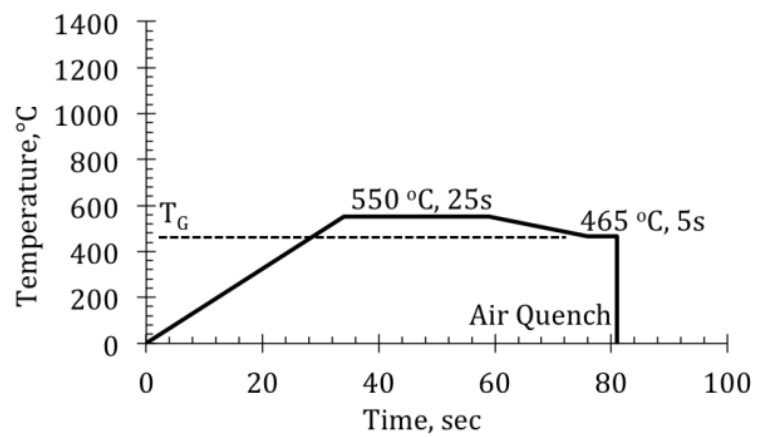

(b)

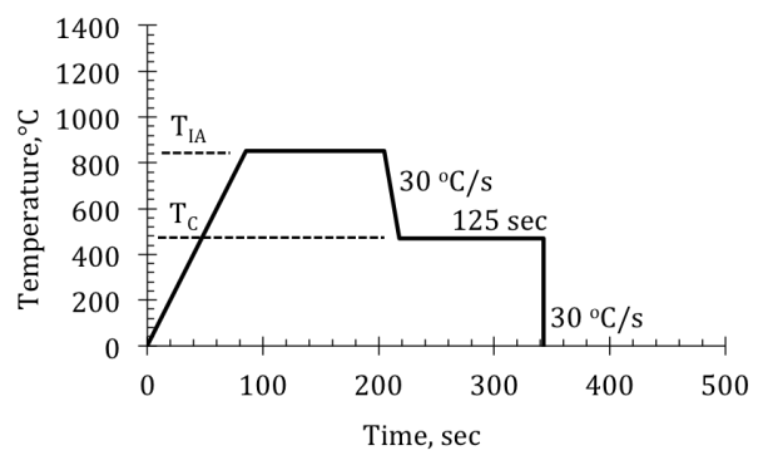

(c)

Figure 2: Schematics of the thermo-mechanical processing schedules denoted as (a) TMP-S and TMP-L for short and long coiling times ( $t_{c}=125$ and $1200 \mathrm{~s}$ ), (b) TMP-LG where an additional galvanising treatment is undertaken after TMP-L and, (c) IA-G involving intercritical annealing galvanising treatment. $\mathrm{T}_{\mathrm{FR}}=$ finish rolling temperature; $\mathrm{T}_{\mathrm{AC}}=$ start of accelerated cooling temperature, $\mathrm{T}_{\mathrm{C}}=$ coiling temperature; $\mathrm{T}_{\mathrm{G}}=$ galvanising temperature; $\mathrm{T}_{\mathrm{IA}}=$ intercritical annealing temperature. 


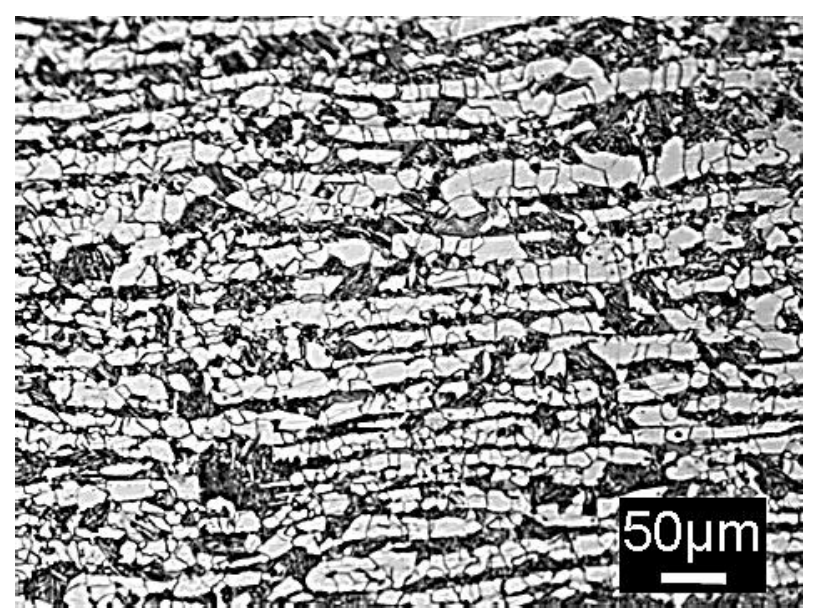

(a)

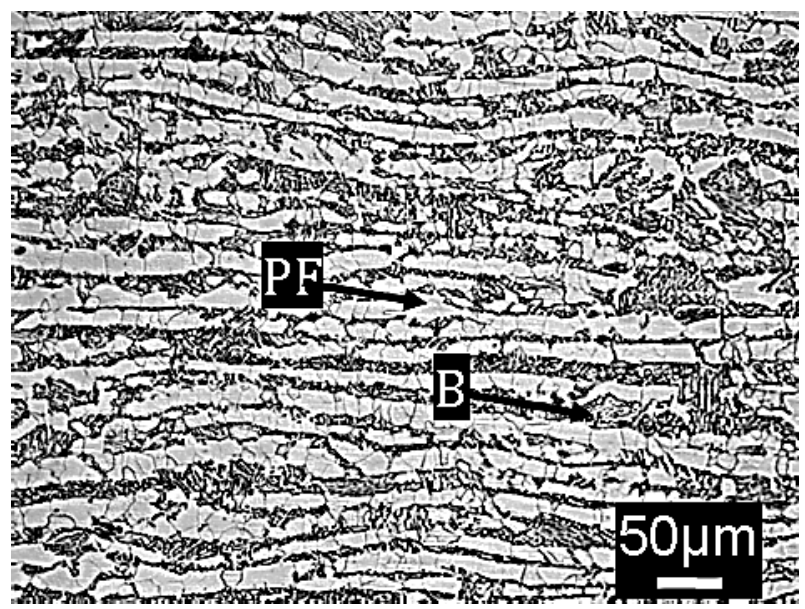

(c)

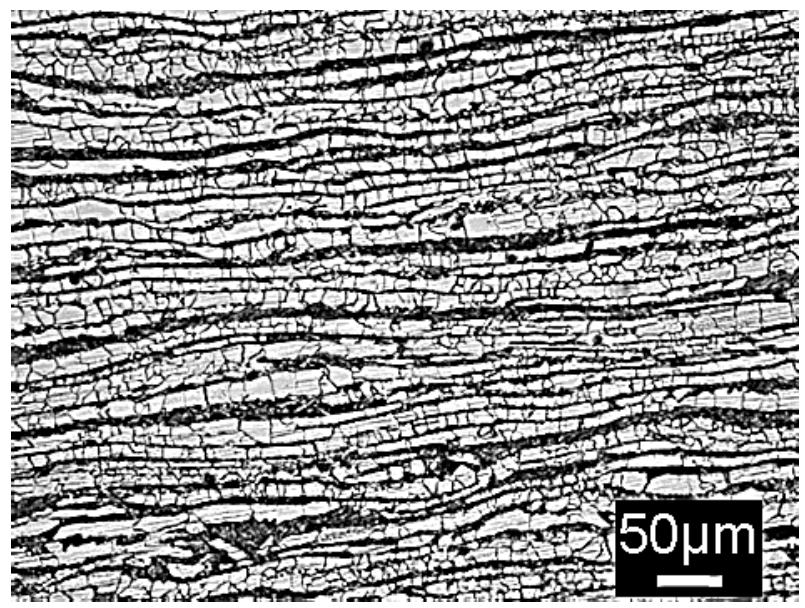

(e)

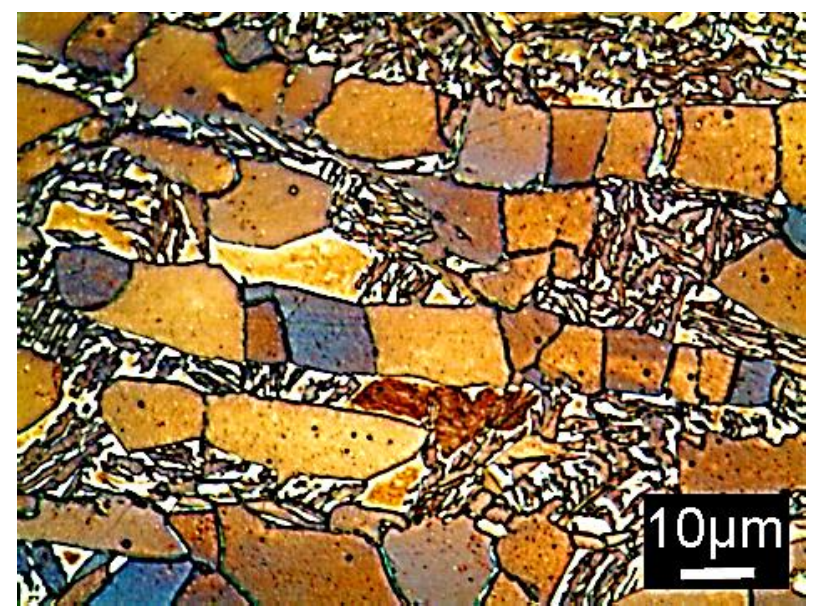

(b)

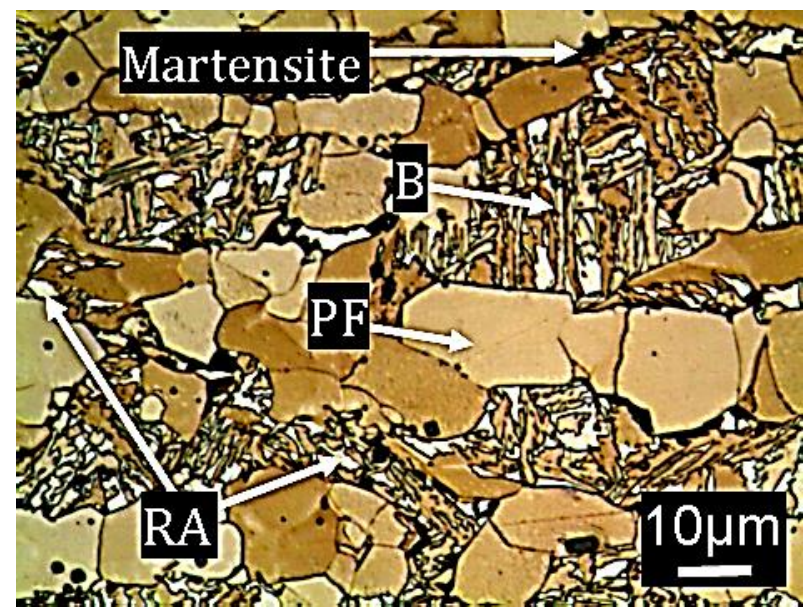

(d)

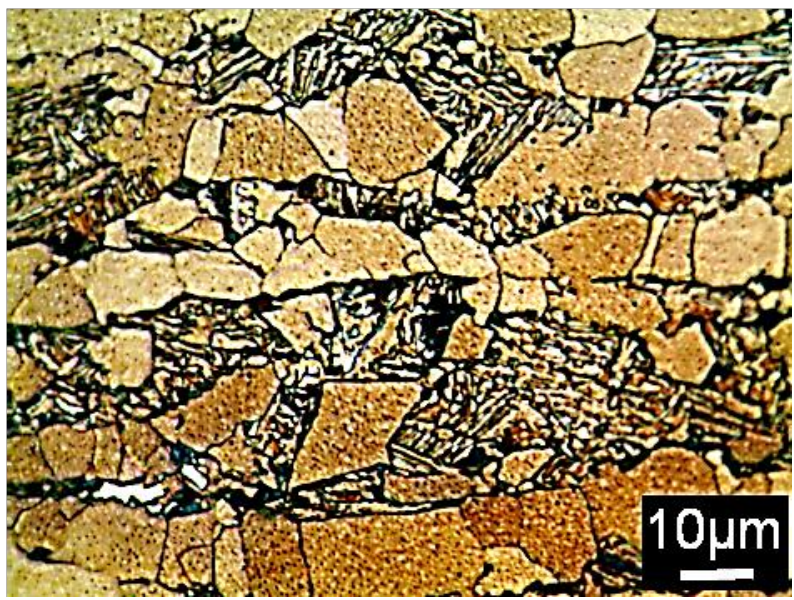

(f)

Figure 3: (a, c, e) Nital and (b, d, f) colour etched microstructures of the base steel after (a, b) TMP-S, (c, d) TMP-L and (e, f) and TMP-LG schedules. $\mathrm{PF}=$ polygonal ferrite; $\mathrm{BF}=$ bainitic ferrite; $\mathrm{M}=$ martensite and $\mathrm{RA}=$ retained austenite. 


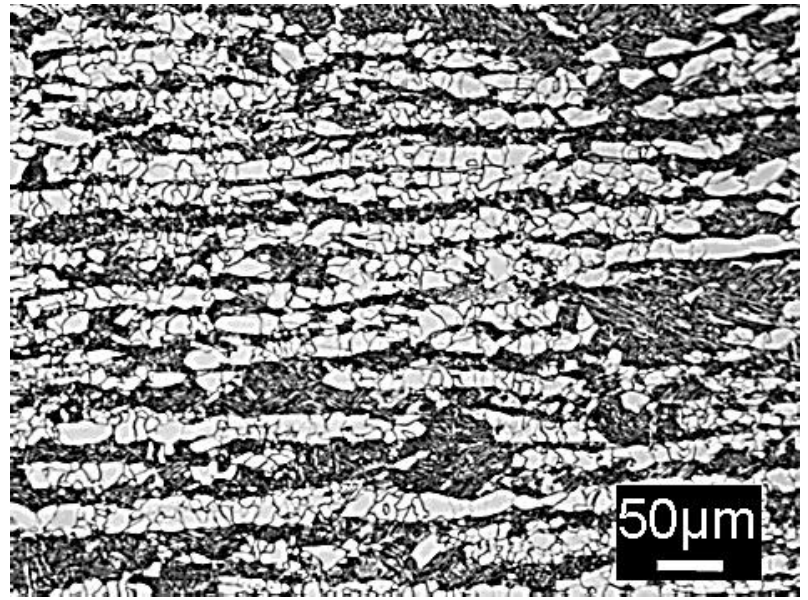

(a)

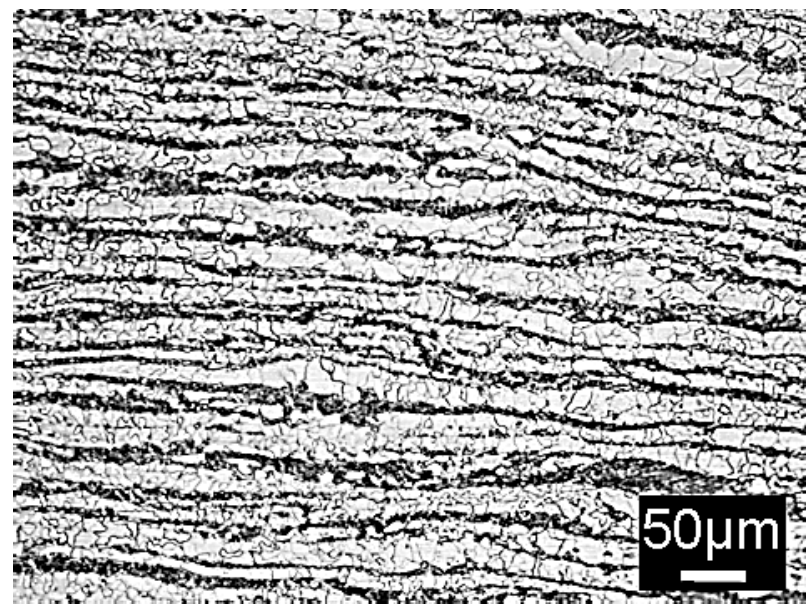

(c)

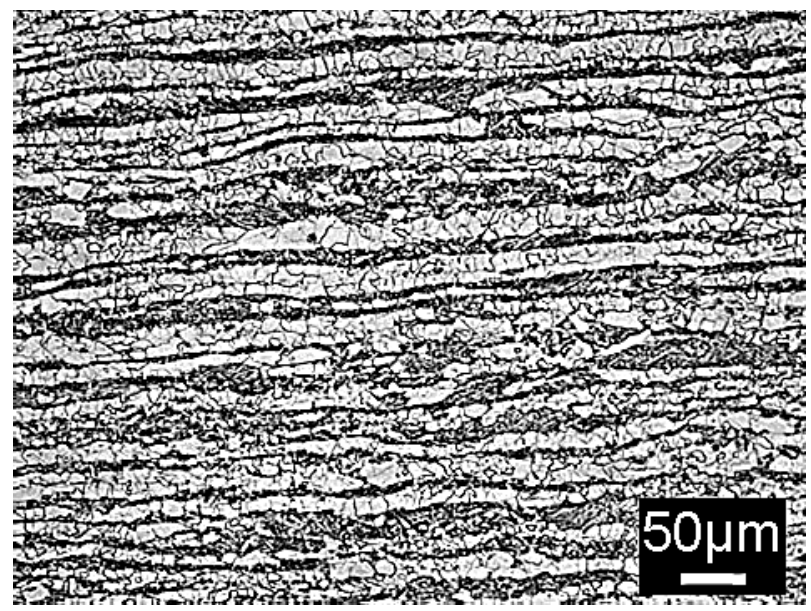

(e)

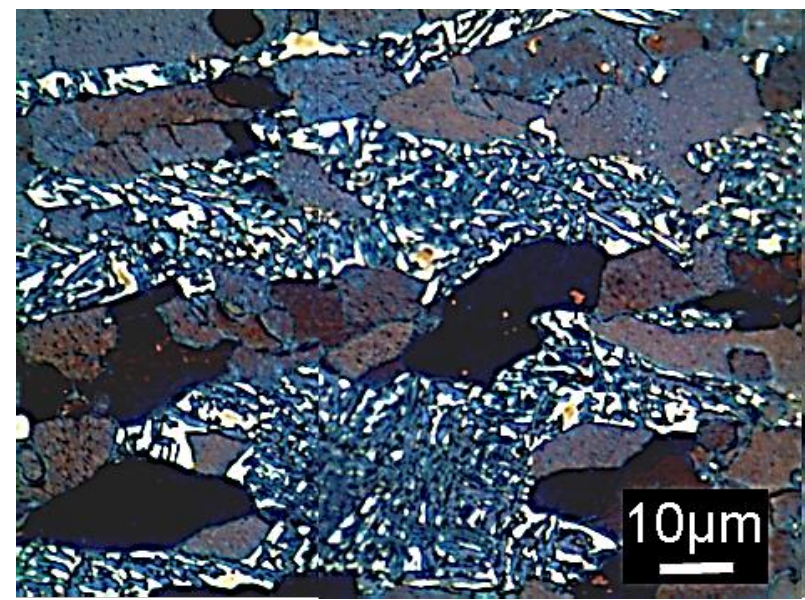

(b)

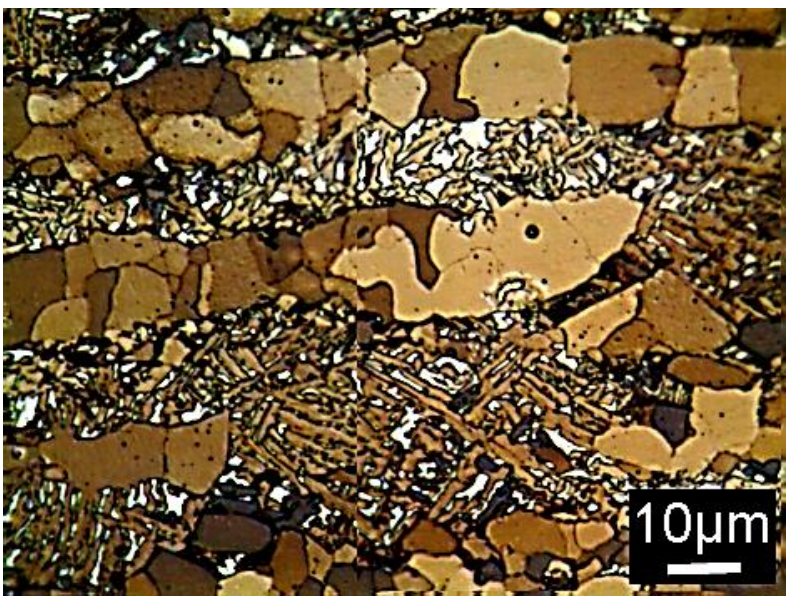

(d)

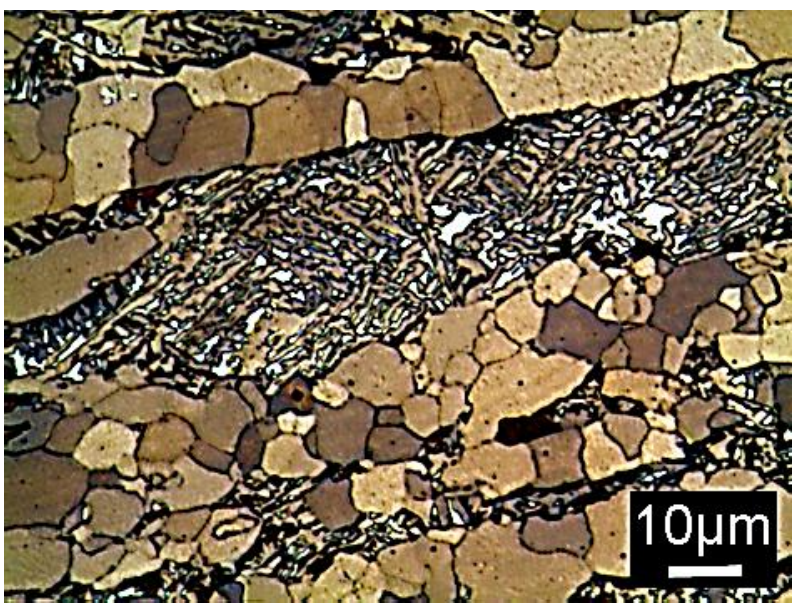

(f)

Figure 4: (a, c, e) Nital and (b, d, f) colour etched microstructures of the Nb-Ti steel after (a, b) TMP-S, (c, d) TMP-L and (e, f) and TMP-LG schedules. 


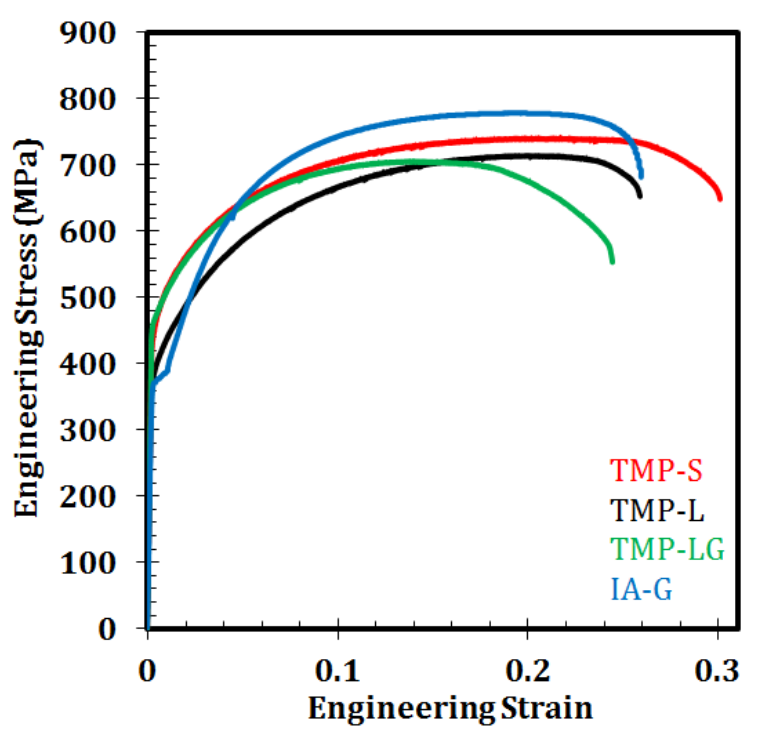

(a)

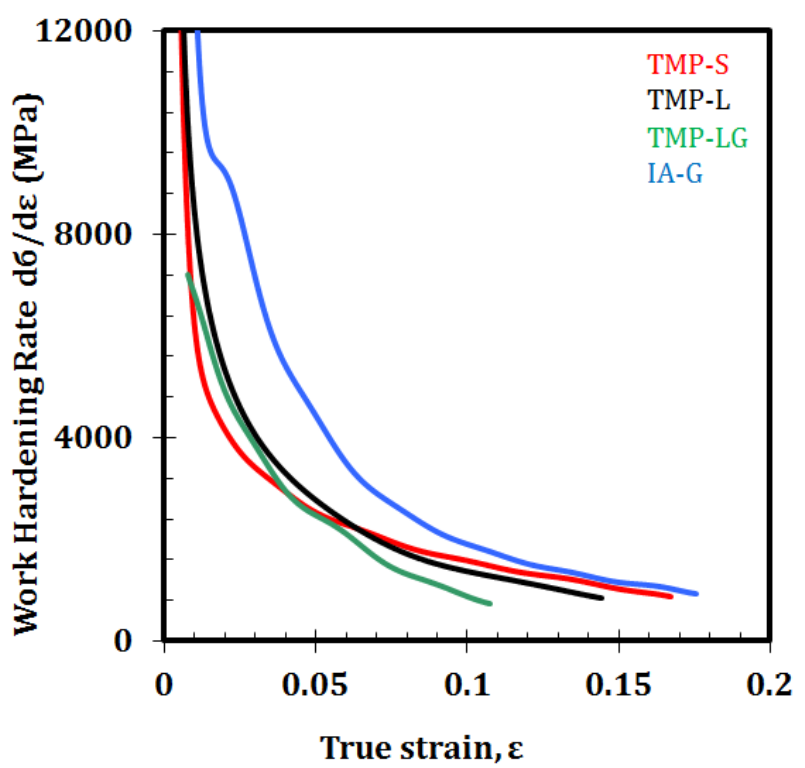

(c)

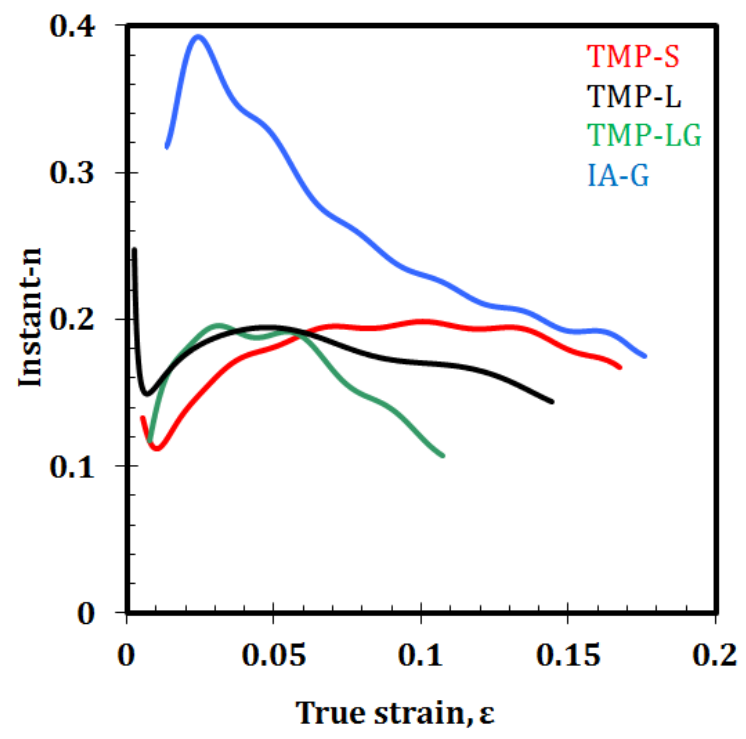

(e)

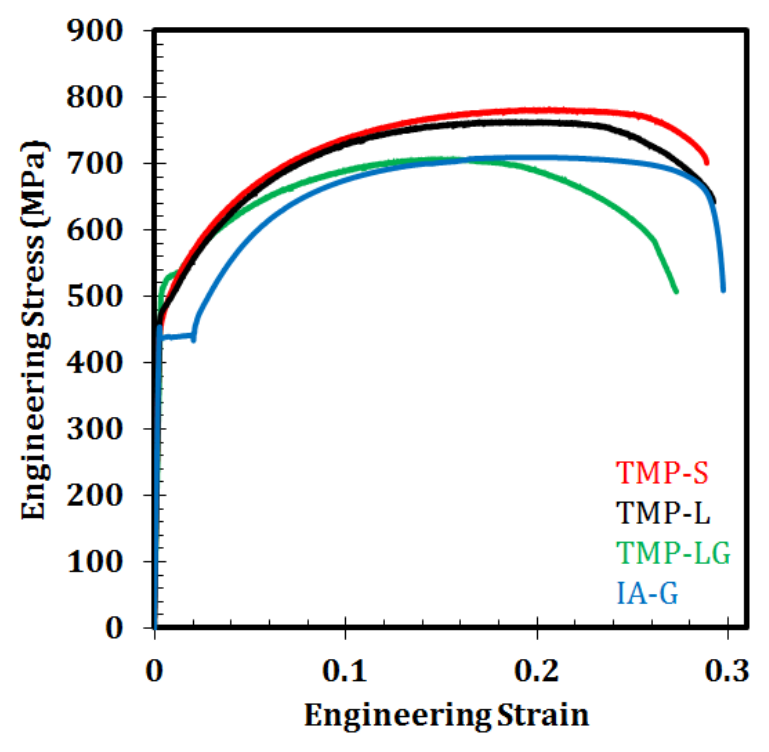

(b)

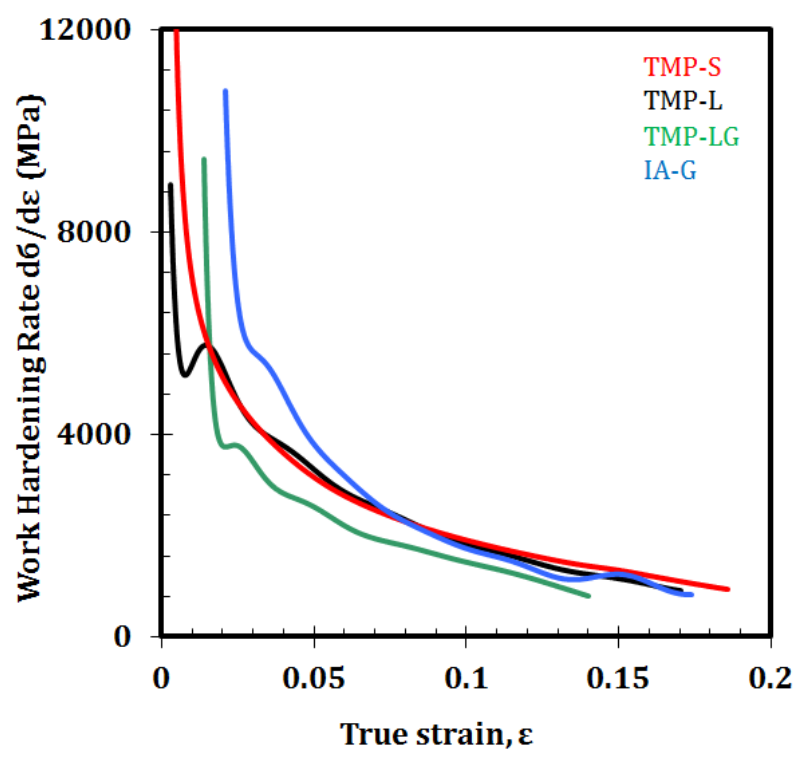

(d)

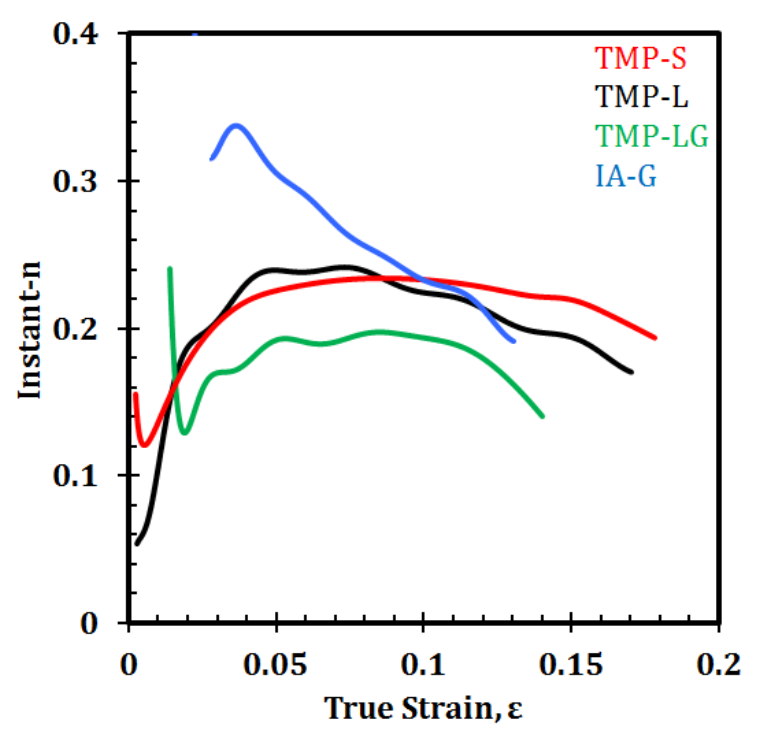

(f) 
Figure 5: The variation in (a, b) the engineering stress versus strain, (c, d) the work hardening rate versus true strain and, $(e, f)$ the instantaneous $n$-value versus true strain in the $(a, c, e)$ base and $(b, d, f)$ Nb-Ti steels.

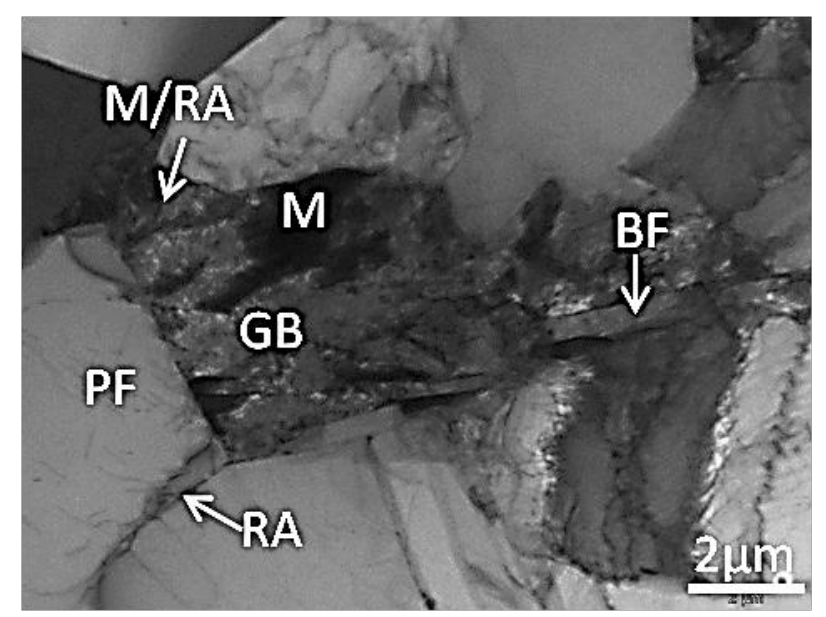

(a)

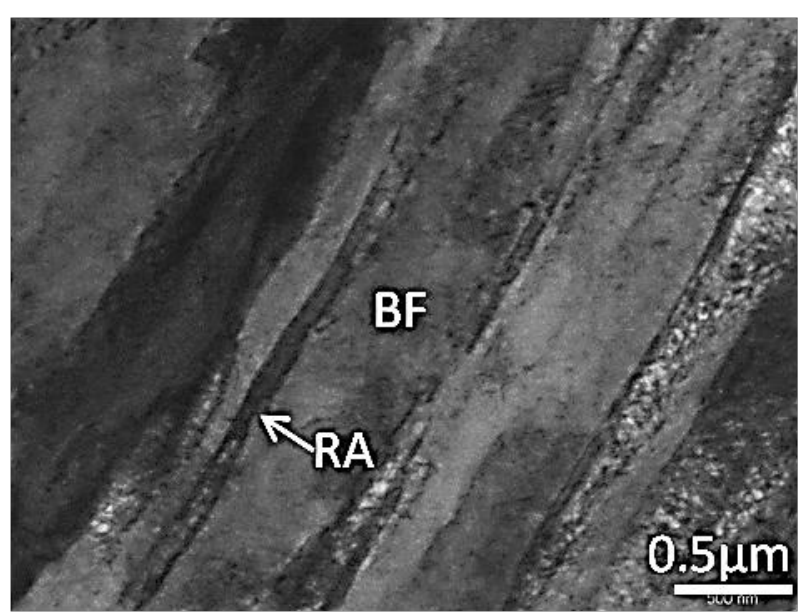

(b)

Figure 6: Representative bright field micrographs of the various bainitic morphologies seen in the base steel after the TMP-L schedule. $\mathrm{PF}=$ polygonal ferrite; $\mathrm{BF}=$ bainitic ferrite; $\mathrm{M}=$ martensite and $\mathrm{RA}=$ retained austenite. 


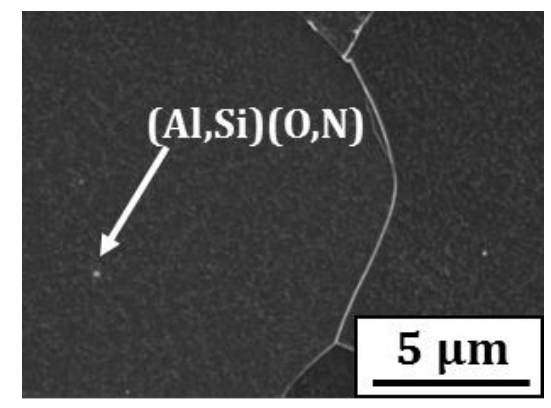

(a)

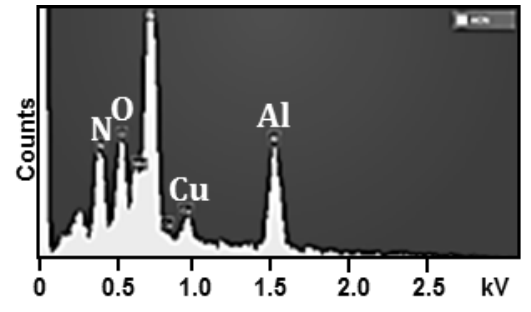

(d)

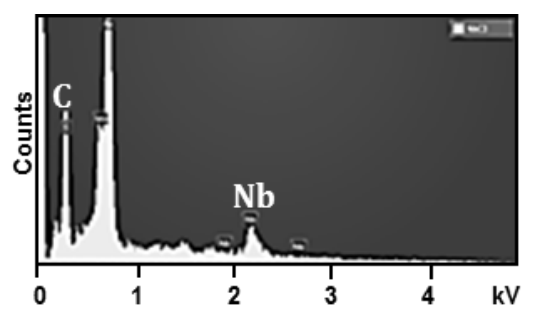

(g)

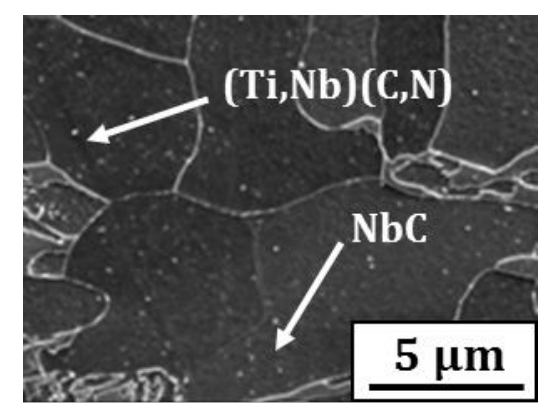

(b)

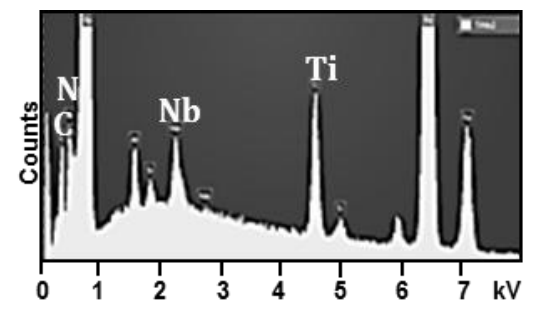

(e)

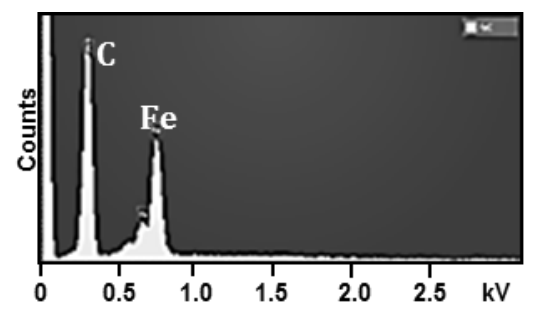

(h)

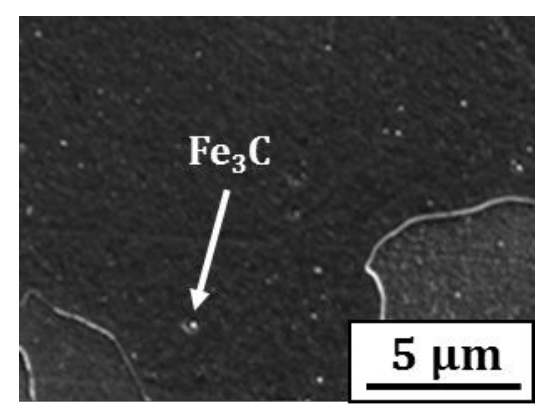

(c)

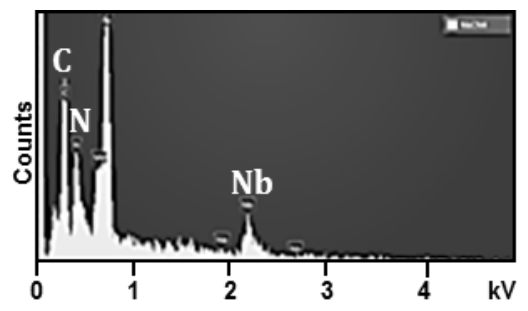

(f)

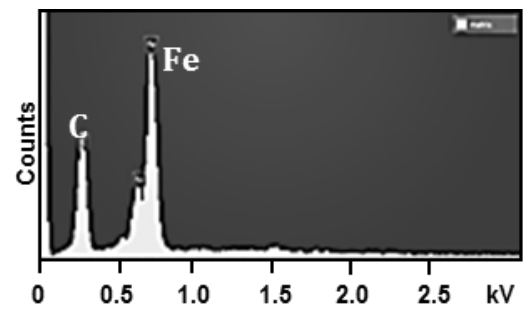

(i)

Figure 7: Representative secondary electron micrographs of the (a) TMP-L base, (b) TMP-L $\mathrm{Nb}-\mathrm{Ti}$ and, (c) TMP-LG Nb-Ti steels. (d-i) Example EDS spectra of (d) an $\mathrm{Al}(\mathrm{O}, \mathrm{N})+\mathrm{Cu}$ particle from the TMP-L base steel, (e) (Ti,Nb) $(\mathrm{C}, \mathrm{N}),(\mathrm{f}) \mathrm{Nb}(\mathrm{C}, \mathrm{N})$ and $(\mathrm{g}) \mathrm{NbC}$ particles from the TMP-L $\mathrm{Nb}$-Ti steel, (h) $\mathrm{Fe}_{3} \mathrm{C}$ particles in and, (i) the matrix of the TMP-LG Nb-Ti steel. 


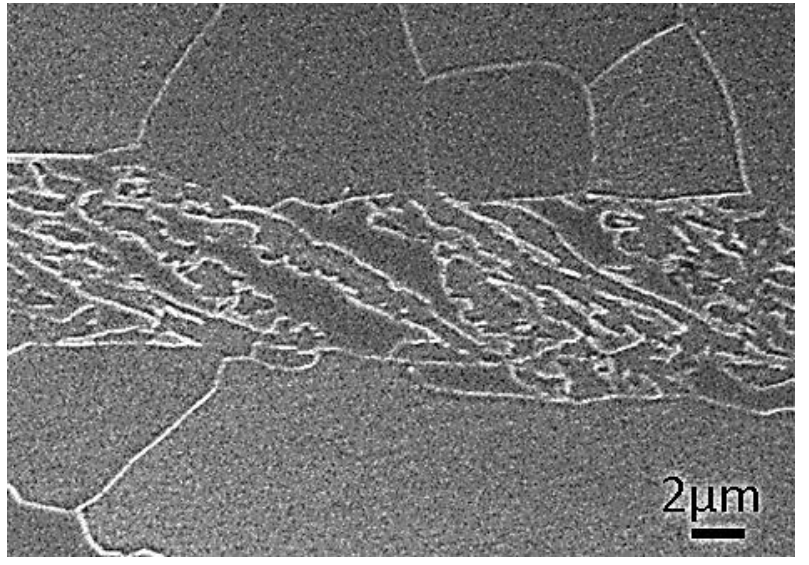

(a)

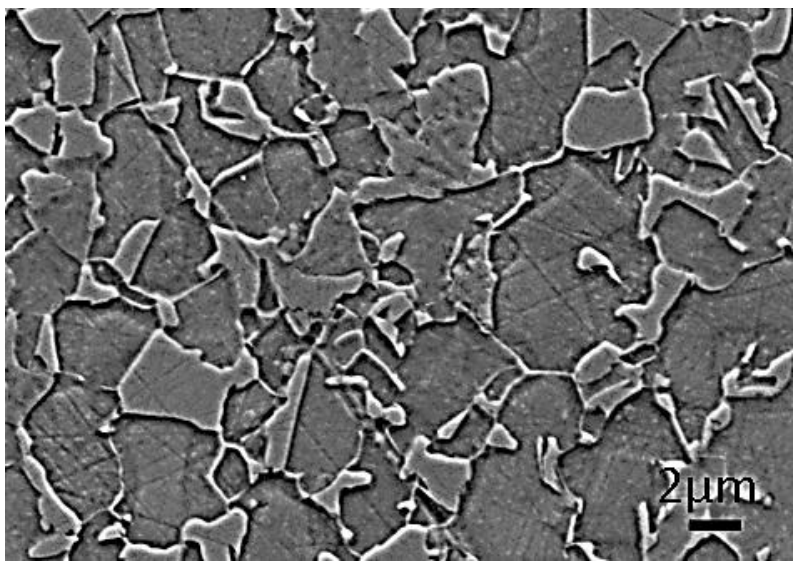

(c)

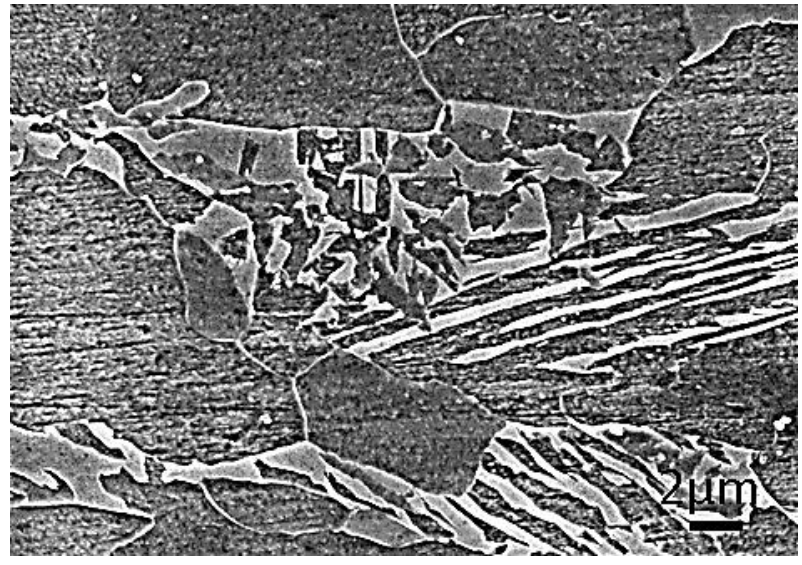

(b)

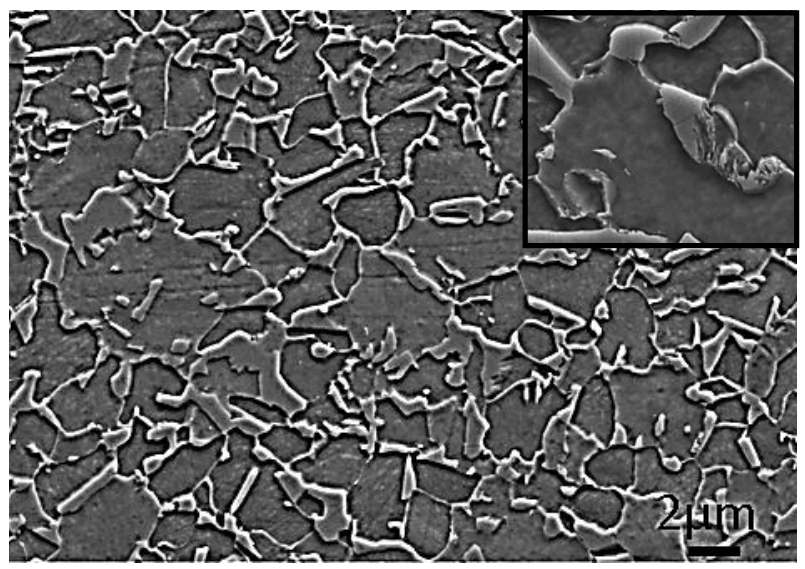

(d)

Figure 8: Representative secondary electron micrographs after (a, b) TMP-S and (c, d) IA-G processing of the $(\mathrm{a}, \mathrm{c})$ base and (b, d) Nb-Ti steels. In (d), the inset shows the initial decomposition of the RA phase. 


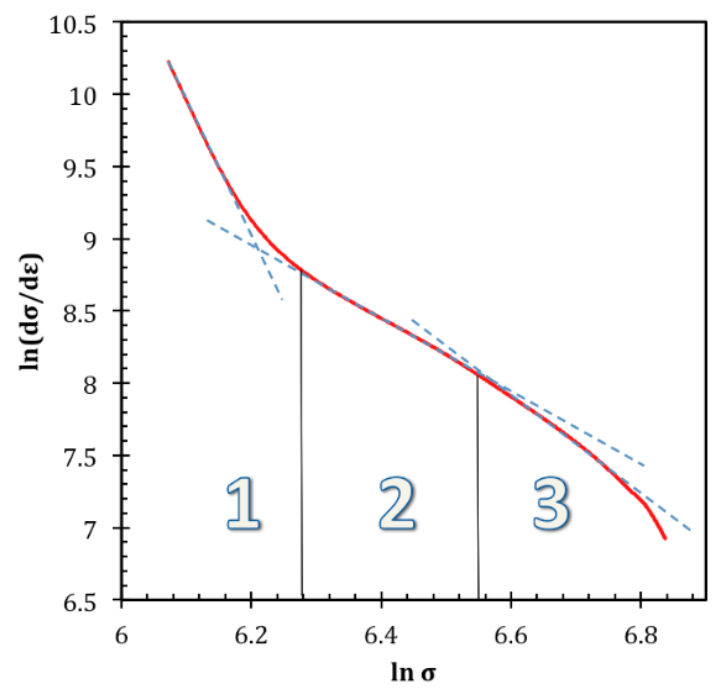

(a)

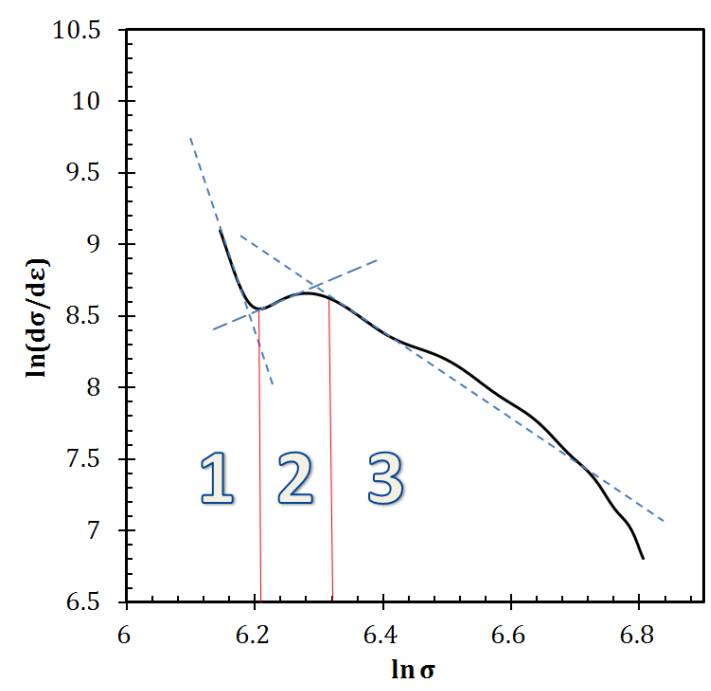

(b)

Figure 9: Representative work hardening behaviors shown using examples of $\mathrm{Nb}$-Ti steel after (a) TMP-S and (b) TMP-L schedules. Based on the modified C-J analysis, three distinct stages of work hardening can be seen. 


\section{Tables list}

Table 1: The nominal chemical composition of the two low Si TRIP steels in wt.\%.

Table 2: A summary of the simulation processing parameters, the phase statistics and the mechanical properties of the base and $\mathrm{Nb}$-Ti steels.

Table 3: Comparison of the modified Crussard-Jaoul (C-J) analysis with the experimental results at the different stages of work hardening in the base and $\mathrm{Nb}$-Ti steels. 
Table 1: The nominal chemical composition of the two low Si TRIP steels in wt.\%.

\begin{tabular}{cccccccc}
\hline Steel & $\mathbf{C}$ & $\mathbf{M n}$ & $\mathbf{S i}$ & $\mathbf{A l}$ & $\mathbf{P}$ & $\mathbf{N b}$ & $\mathbf{T i}$ \\
\hline Base & 0.15 & 2.00 & 0.30 & 1.00 & 0.05 & - & - \\
$\mathrm{Nb}-\mathrm{Ti}$ & 0.15 & 2.00 & 0.30 & 1.00 & 0.01 & 0.03 & 0.02 \\
\hline
\end{tabular}

Table 2: A summary of the simulation processing parameters, the phase statistics and the mechanical properties of the base and $\mathrm{Nb}$-Ti steels.

\begin{tabular}{|c|c|c|c|c|c|c|c|c|c|c|c|c|c|}
\hline \multirow{4}{*}{ Steel } & \multirow{4}{*}{ Schedule } & \multicolumn{4}{|c|}{ Processing parameters } & \multicolumn{4}{|c|}{ Phase statistics } & \multicolumn{4}{|c|}{ Mechanical properties } \\
\hline & & \multirow[t]{2}{*}{$\mathrm{T}_{\mathrm{AC}}$} & \multirow[t]{2}{*}{$\mathrm{T}_{\mathrm{C}}$} & \multirow[t]{2}{*}{$\mathrm{t}_{\mathrm{c}}$} & \multirow[t]{2}{*}{$\mathrm{T}_{\mathrm{G}}$} & \multicolumn{2}{|c|}{$\begin{array}{l}\text { Polygonal } \\
\text { ferrite }\end{array}$} & \multicolumn{2}{|c|}{$\begin{array}{l}\text { Retained } \\
\text { austenite }\end{array}$} & \multirow[t]{2}{*}{ YS } & \multirow[t]{2}{*}{ UTS } & \multirow[t]{2}{*}{ UE } & \multirow[t]{2}{*}{$\mathrm{TE}$} \\
\hline & & & & & & $\mathrm{VF}$ & & $\mathrm{VF}$ & $\mathrm{C}$ & & & & \\
\hline & & ${ }^{\circ} \mathrm{C}$ & ${ }^{\circ} \mathrm{C}$ & $s$ & ${ }^{\circ} \mathrm{C}$ & $\%$ & $\mu \mathrm{m}$ & $\%$ & wt. $\%$ & $\mathrm{MPa}$ & $\mathrm{MPa}$ & $\%$ & $\%$ \\
\hline \multirow{4}{*}{ Base } & TMP-S & 680 & 465 & 125 & -- & $48 \pm 1$ & $12 \pm 8$ & $7 \pm 1$ & $1.3 \pm 0$ & $491 \pm 35$ & $745 \pm 6$ & $20 \pm 3$ & $29 \pm 2$ \\
\hline & TMP-L & 680 & 470 & 1200 & -- & $47 \pm 1$ & $12 \pm 6$ & $4 \pm 1$ & $1.2 \pm 0$ & $445 \pm 44$ & $722 \pm 34$ & $15 \pm 0$ & $25 \pm 4$ \\
\hline & TMP-LG & 665 & 470 & 1200 & 465 & $46 \pm 3$ & $12 \pm 8$ & $2 \pm 1$ & $1.1 \pm 0.1$ & $476 \pm 6$ & $699 \pm 9$ & $12 \pm 2$ & $24 \pm 1$ \\
\hline & IA-G & -- & 465 & 125 & -- & 50 & 5 & 10 & 1.1 & 360 & 787 & 19 & 26 \\
\hline \multirow{4}{*}{$\mathrm{Nb}-\mathrm{Ti}$} & TMP-S & 690 & 465 & 125 & -- & $45 \pm 1$ & $10 \pm 6$ & 7 & $1.2 \pm 0$ & 474 & 782 & 20 & 29 \\
\hline & TMP-L & 690 & 470 & 1200 & -- & $49 \pm 3$ & $8 \pm 4$ & $13 \pm 0$ & $1.1 \pm 0$ & $476 \pm 7$ & $749 \pm 20$ & $18 \pm 0$ & $29 \pm 0$ \\
\hline & TMP-LG & 690 & 470 & 1200 & 465 & $47 \pm 1$ & $11 \pm 7$ & $6 \pm 4$ & $1 \pm 0.1$ & $499 \pm 6$ & $685 \pm 32$ & $13 \pm 2$ & $26 \pm 2$ \\
\hline & IA-G & -- & 465 & 125 & -- & 50 & 5 & 8 & 1.1 & 438 & 710 & 20 & 30 \\
\hline
\end{tabular}

Legend: $\mathrm{T}_{\mathrm{AC}}=$ accelerated cooling start temperature; $\mathrm{T}_{\mathrm{C}}=$ coiling temperature; $\mathrm{t}_{\mathrm{c}}=$ coiling time; $\mathrm{T}_{\mathrm{G}}=$ galvanising temperature; $\mathrm{VF}=$ volume fraction; $\mathrm{GS}=$ grain size; $\mathrm{C}=$ carbon content; $\mathrm{YS}=0.2 \%$ proof stress; UTS = ultimate tensile strength; $\mathrm{UE}=$ uniform elongation; $\mathrm{TE}=$ total elongation . 
Table 3: Comparison of the modified Crussard-Jaoul (C-J) analysis with the experimental results at the different stages of work hardening in the base and $\mathrm{Nb}$-Ti steels.

\begin{tabular}{|c|c|c|c|c|c|}
\hline \multirow{3}{*}{ Steel } & \multirow{3}{*}{ Schedule } & \multicolumn{3}{|c|}{ Modified C-J } & \multirow{3}{*}{$\begin{array}{c}\text { Experimental } \\
\mathrm{m}^{\dagger}\end{array}$} \\
\hline & & Stage 1 & Stage 2 & Stage 3 & \\
\hline & & $\mathrm{m}_{1}^{*}$ & $\mathrm{~m}_{2}$ & $\mathrm{~m}_{3}$ & \\
\hline \multirow{4}{*}{ Base } & TMP-S & 7.66 & 4.05 & 4.91 & 6.18 \\
\hline & TMP-L & 12.96 & 2.87 & 4.18 & 7.05 \\
\hline & TMP-LG & 7.25 & 3.89 & 6.47 & 10.03 \\
\hline & $\mathrm{IA}-\mathrm{G}$ & 1.99 & 1.41 & 5.02 & 6.06 \\
\hline \multirow{4}{*}{$\mathrm{Nb}-\mathrm{Ti}$} & TMP-S & 10.20 & 3.53 & 4.11 & 5.46 \\
\hline & TMP-L & 13.69 & -0.98 & 4.03 & 5.97 \\
\hline & TMP-LG & 21.25 & 0.66 & 4.95 & 7.91 \\
\hline & $\mathrm{IA}-\mathrm{G}$ & 8.48 & 2.05 & 5.42 & 6.09 \\
\hline
\end{tabular}

*1- $\mathrm{m}_{1-3}=$ slopes at Stages 1 to 3

$t_{\mathrm{m}}=1 /\left(\varepsilon_{\mathrm{u}}-\varepsilon_{\mathrm{y}}\right)$; where $\varepsilon_{\mathrm{u}}=$ maximum uniform true strain, $\varepsilon_{\mathrm{y}}=$ strain at $0.2 \%$ offset proof stress or the strain where Lüders banding is completed. 